\title{
Recordkeeping in council-controlled organisations: An investigation into local body involvement and the implementation of formal recordkeeping programmes
}

\section{By}

\section{Vanessa King}

\author{
Submitted to the School of Information Management, \\ Victoria University of Wellington \\ in partial fulfilment of the requirements for the degree of \\ Master of Information Studies
}

June 2013 


\section{Abstract}

In New Zealand council-controlled organisations (CCOs) play an important role in the conduct of local government's affairs, and in recognition of this they are subject to the Public Records Act 2005. The purpose of the study is to investigate the extent to which local bodies are involved in CCO recordkeeping programmes, the motivations for and barriers to their involvement, and whether formal recordkeeping programmes are being implemented in CCOs. The study used an online questionnaire to collect data from CCOs and staff overseeing recordkeeping in local bodies. The results show that though some local bodies take part in CCO recordkeeping programmes, involvement is often occasional and not necessarily grounded in a formal agreement. In some cases perceptions about the status of CCOs apparently drive involvement, while a lack of guidance, decision-making and resources can inhibit participation. Small CCOs in the completed sample did not show strong signs of having implemented formal recordkeeping programmes, but due to the response rate this finding cannot be generalised to all CCOs. The study brings attention to previously undocumented issues with CCO recordkeeping, and presents the case that CCOs and local body recordkeepers are in need of appropriate advisory support. There is still much that is unknown about CCOs' attitudes to toward their legal recordkeeping obligations, the barriers they face to implementing formal recordkeeping programmes, and the assistance they require.

Keywords: accountability, council-controlled organisations, local government, open government, recordkeeping 


\section{Table of Contents}

Introduction ................................................................................................................6

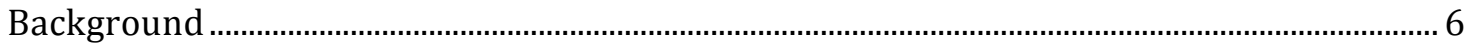

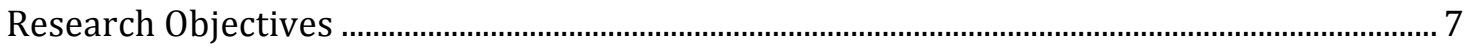

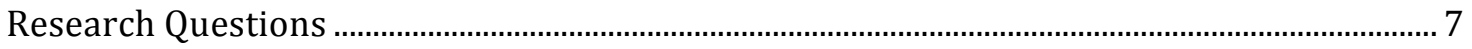

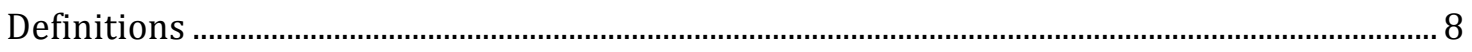

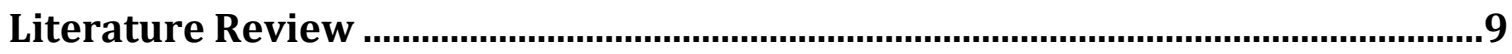

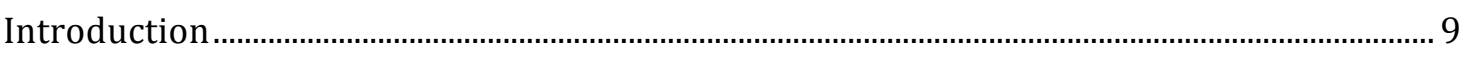

Identity, governance and accountability in SOES, LATES and CCOs ........................................ 10

Transparency, recordkeeping and information culture ............................................................ 13

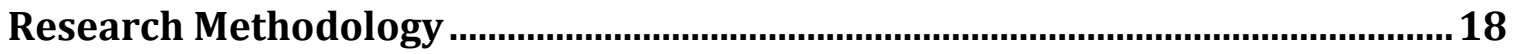

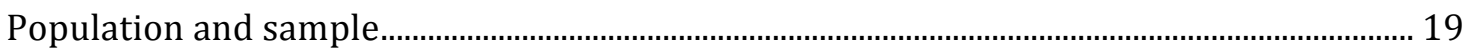

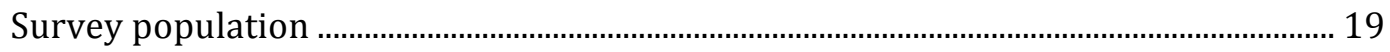

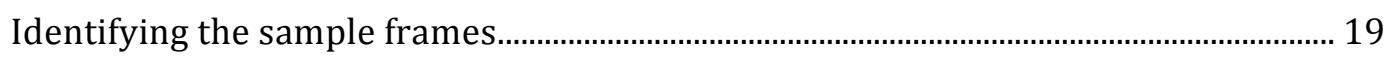

Exclusion from the sample frames ................................................................................ 20

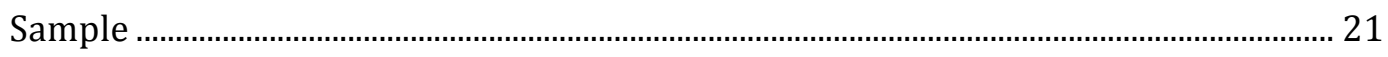

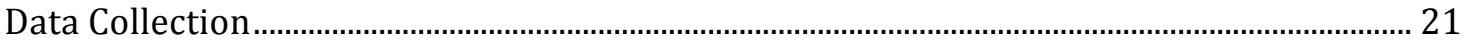

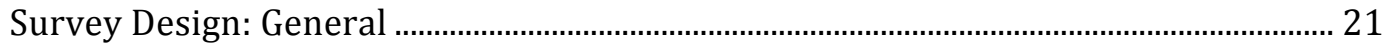

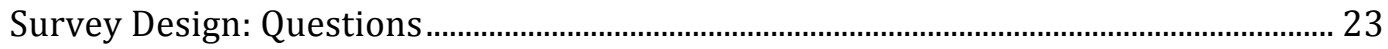

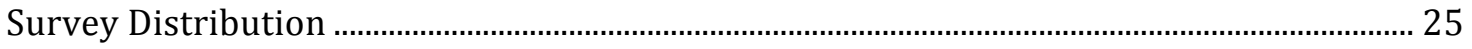

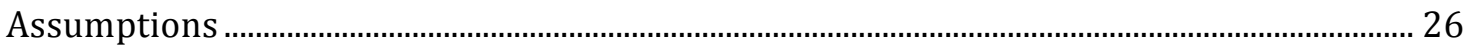

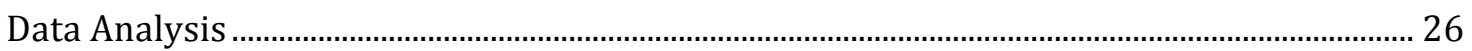

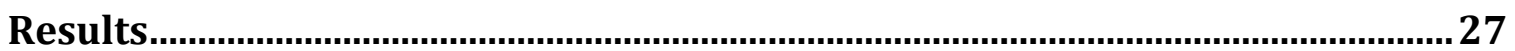

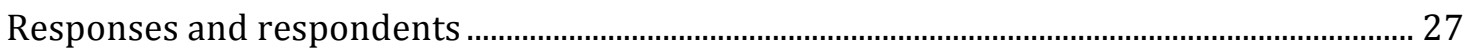

Are local bodies involved with CCO recordkeeping programmes?............................................. 28

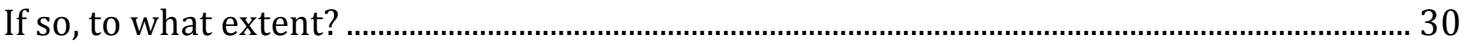

What motivates local body involvement and what are the barriers? .......................................... 32

Are formal recordkeeping programmes being implemented in CCOs? ..................................... 34

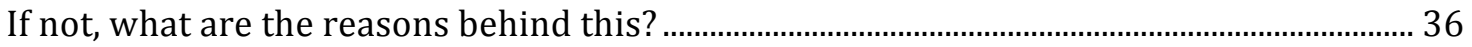

Influence of organisation size, type of CCO or type of local body ……...................................... 37 


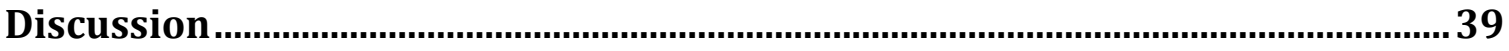

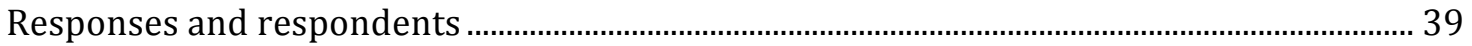

Are local bodies involved with CCO recordkeeping programmes?........................................... 40

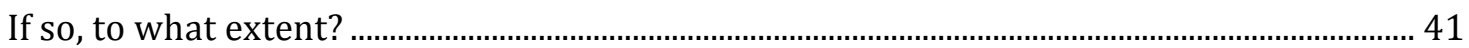

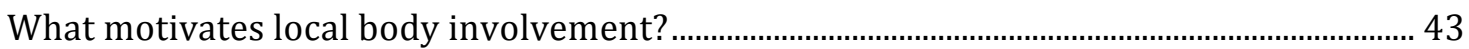

What are the barriers to local body involvement? ......................................................................... 44

Are formal recordkeeping programmes being implemented in CCOs? .................................. 46

Influence of organisation size, type of CCO or type of local body ……...................................... 46

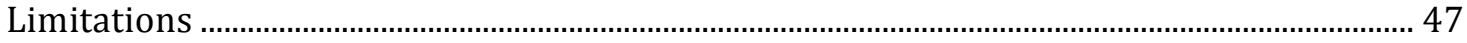

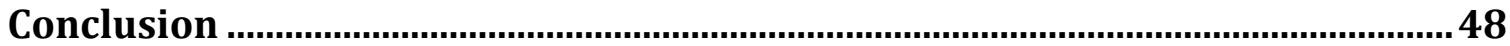

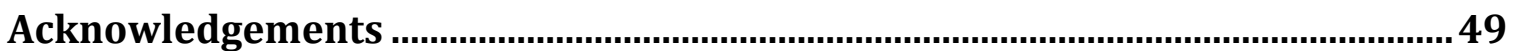

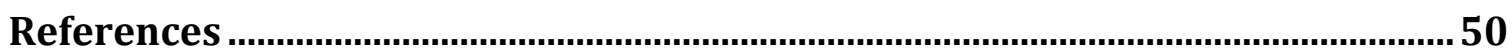

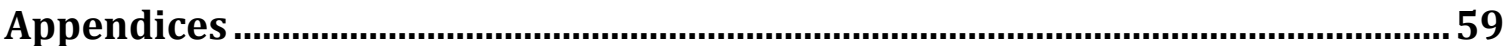

Appendix I: Information request sent to local bodies, 29 November 2012 ........................... 59

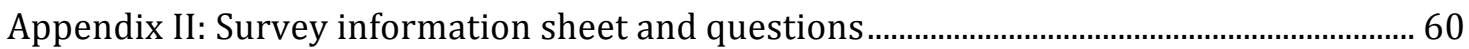

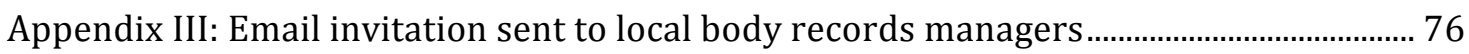

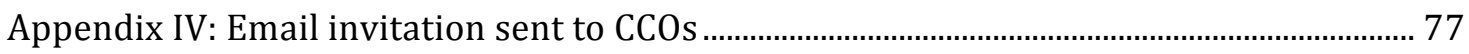

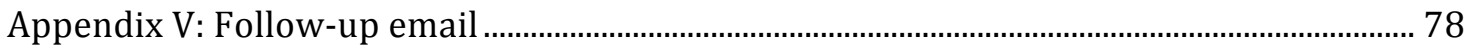




\section{Figures}

Figure 1: Frequency of organisation types represented in the dataset........................... 27

Figure 2: Frequency of local body involvement with CCO recordkeeping according to respondents.

Figure 3: Perspective of local body respondents on their organisation's involvement in CCO recordkeeping

Figure 4: CCO respondents with no local body involvement in their recordkeeping and no specialised recordkeeping staff

\section{Tables}

Table 1: Item-level nonresponse rates per number of unanswered items

Table 2: Cross tabulation of the number of CCOs controlled by a local body with local body involvement in CCO recordkeeping. 


\section{Background}

A fundamental purpose of the Public Records Act 2005 (PRA) is to ensure the creation and maintenance of full and accurate records of the affairs of New Zealand's central and local government (Public Records Act, 2005). Fulfilment of that purpose is understood to support open and accountable government, although it is the partnership of the PRA with official information legislation, along with a favourable information culture within an organisation, that truly enables open government (New Zealand Law Commission, 2010; Oliver, 2011). In the local government context the PRA "defines the boundaries of the information held by an agency," (New Zealand Law Commission, 2010, p.358), while the Local Government Official Information and Meetings Act 1987 (LGOIMA) governs access to that information. Local government is subject to a lighter regulatory framework under the PRA than central government, being outside Archives New Zealand's audit and transfer programmes (Government Administration Committee, 2005). Entities in which a local body has a controlling interest are included within the purview of both the PRA and LGOIMA. These entities, referred to throughout as council-controlled organisations (CCOs), emerged from the reform of New Zealand's local government in 1989 and are the subject of the study (Local Government Amendment Act (No.2), 1989).

The motivation for investigating CCOs stemmed from my observation, during time spent working for a territorial council, that it can be unclear to local body recordkeepers exactly what their responsibilities are regarding CCO recordkeeping. CCOs, such as Auckland Council's "substantive" CCOs (Local Government (Auckland Council) Act, 2009) may own or manage millions of dollars worth of assets on behalf of ratepayers and are no strangers to mismanagement; Environment Canterbury's Target Pest, which went into receivership in 2007, is one such example ("Sorry tale," 2009). There is virtually no publically available research into CCO recordkeeping and CCOs are excluded from the PRA audit programme. 


\section{Research Objectives}

There is a definite need then for evidence that CCOs' records are being managed to support open government. The specific objectives of the study are to examine the views of staff overseeing recordkeeping in local bodies on their level of responsibility for CCO recordkeeping, the extent to which formal recordkeeping programmes are in place within CCOs, and if this varies according to the size or type of CCO or local body. Information was solicited from both local bodies, especially as regards the first objective, and CCOs, using quantitative survey methods.

\section{Research Questions}

1. Are local bodies involved with $\mathrm{CCO}$ recordkeeping programmes?

1.1. If so, what is the extent of their involvement and what are their motivations for becoming involved?

1.2. What are the barriers to involvement?

2. Are formal recordkeeping programmes being implemented in CCOs?

2.1. If not, what are the reasons behind this?

3. Do the organisation size, type of CCO or type of local body have any influence on the other research questions? 


\section{Definitions}

Council-controlled organisation (CCO): Used here to collectively refer to for- (CCTO) and non-profit (CCO) entities in which a local body has a controlling interest, as they are defined under section 6 of the Local Government Act 2002 (LGA) (2002).

Local body: Used here to collectively refer to regional councils, territorial authorities and unitary authorities, as they are defined under section 5 of the LGA (2002).

Recordkeeping: The creation and management of records and archives, including the "design, establishment and operation of recordkeeping systems," (Archives New Zealand, 2011) and the incorporation of recordkeeping functionality into business systems.

Transparency: "The deliberate attempt to make available all legally releasable information - whether positive or negative in nature - in a manner that is accurate, timely, balanced, and unequivocal, for the purpose of enhancing the reasoning ability of publics and holding organizations accountable for their actions, policies, and practices," (Rawlins, 2009, p.75). 


\section{Literature Review}

\section{Introduction}

To develop a robust understanding of the nature of CCOs it is prudent to reflect on their beginnings in the reforms that occurred in New Zealand's public sector during the 1980s. These reforms applied the principles of what has since been labelled 'new public management' (NPM), which in essence promoted the introduction of private sector management practices into the public sector (Reid, 2010). The purpose of the reforms was to improve government effectiveness, efficiency, accountability and customer relations, while reducing public expenditure (Boston, Martin, Pallot \& Walsh, 1996). From an NPM perspective the delivery of commercial services by government also inhibited market competition and profitability (Luke, 2010). Consequently, there was a move to fully privatize or corporatise commercial activities, the latter action resulting in state-owned enterprises (SOEs), for central government, and local authority trading enterprises (LATEs). ${ }^{1}$ Corporatisation gave birth to organisations with one foot in the private sector; seeking to operate as successful businesses free from political interference, and the other in the public sector; accountable to central or local government, as majority shareholders, and to the public (Luke, 2010; Roper \& Schoenberger-Orgad, 2011). This liminal position of SOEs and LATEs/CCOs has resulted in complex tensions in the organisationshareholder relationship that are explored in the first half of the literature review.

During the same period that NPM reforms were instigated in New Zealand, freedom of information (FOI) legislation was enacted for both central (1982) and local government (1987). Jimerson (2009, p.252) states that "democracy rests on an informed citizenry;" without the right to access information about the affairs of government citizens' participation in government decision-making is undermined. New Zealand's FOI legislators sought to facilitate greater communication between

${ }^{1}$ Under the Local Government Act 2002 LATEs were redefined as CCOs. 
the citizens and the government by reversing the policy of the Official Secrets Act 1951, under which access to official information was effectively withheld (New Zealand Law Commission, 2010; White, 2007). Yet, FOI legislation alone does not make government more transparent, it is merely "a mechanism to enhance accountability and openness," (White, 2007, p.297). Its proper functioning relies on records being created, maintained and managed in such a way that, if requested, they can be located (New Zealand Law Commission, 2010). In turn, recordkeeping practice and attitudes toward sharing information are shaped by the information culture of the organisation (Oliver, 2011). An organisation may be subject to FOI and recordkeeping laws but if employees "never write anything down that couldn't be released," (White, 2007, p.5) its accountability and openness are questionable. To enable a deeper appreciation of the motivations for the study the second half of the literature review investigates the influences on, and interaction between, transparency, recordkeeping and information culture.

The search for literature revealed a paucity of research into the immediate topic of interest, as well as more general issues surrounding it, like information law, transparency and accountability as they pertain to New Zealand local government. Where possible I have focused on studies conducted in a local government context.

\section{Identity, governance and accountability in SOEs, LATEs and CCOs}

SOEs and LATEs were structured and managed like private sector companies, with boards of directors appointed on the basis of their business acumen, the use of performance monitoring and reporting systems, and a 'statement of corporate intent' as the key document outlining expectations between the organisation and its shareholding ministers or council (Bell, 1998; Boston et al., 1996; Luke, 2010). Until the repeal of the Local Government Act 1974 by the Local Government Act 2002 (LGA) the sole focus of LATEs was to operate as successful businesses, unlike SOEs, which were also required to demonstrate a sense of social responsibility (Local Government Act, 1974, sec 34A; State-Owned Enterprises Act, 1986, sec 4). Cardow 
(2005) found that LATE managers identified strongly with the private sector and its language of entrepreneurship, to the point where they did not view their organisations as public businesses. In multiple cases he encountered a "trenchant disavowal," (Cardow, 2005, p.221) by interviewees that they were local government employees, a perception that council ownership constrained the business, and the notion of serving 'customers' rather providing a public service to citizens. The study concluded that LATEs' lack of identification with the public sector was unfitting and called for further research into what extent they rejected their public service aspect (Cardow, 2005).

Cardow (2005) disputed the complaints of LATE managers that councils did not behave like owners, however, research by Bell (1998) suggested that councillors were overly involved in LATEs and had difficulty discerning the line between shareholding and management. The elected members Bell (1998) spoke with felt that councillor representation on LATE boards assuaged public distrust of the LATE structure, and they considered themselves politically accountable to the electorate for LATE decisions. This led them to expect more information from and control over their LATEs than is typically appropriate for an investor (Bell, 1998). Bell (1998) concluded that to better demarcate the position of the council as owner informal communication structures should be avoided and elected members should not be appointed to LATE boards, as this caused a conflict of interest between acting for the business versus the community.

The degree of control a council should have over CCOs remains a current subject for debate. Over ten years on from Bell's (1998) findings, a governance review of Dunedin City Council's (DCC) CCOs detected "dysfunctional behaviours within the DCC group," (Larsen Consulting, 2012, p.13), and to improve this situation it was recommended that elected councillors and DCC senior management should not hold CCO director positions. The Controller and Auditor-General (2012) reported that tensions were growing between the Auckland Council and its substantive CCOs. She 
advised that the Council's emphasis on formal governance reporting and monitoring frameworks for CCOs could place CCO independence at risk, create a compliance burden whereby the governance function of the CCO board was undermined, and was detrimental to building trust (Controller and Auditor-General, 2012). But, from the perspective of one Auckland councillor "the biggest problem is the CCOs think their boards are their bosses, not us," (Howie, 2012).

The participants in Bell's (1998) study raised the issue of councils being held politically accountable for LATEs in the minds of the public, despite their autonomy. The interplay between public perception and politics seems to pervade the matter of CCO and SOE accountability. SOE senior executives interviewed by Luke (2010) remarked on the pressure of public expectations that originated from the somewhat misconceived view that SOEs were taxpayer-funded organisations. The executives felt bound to consider those expectations since the public held the government accountable for any SOE failures, and if the government came under fire from the public this could affect its appetite for risk with regard to SOE business decisions (Luke, 2010). Politics may lead the government to underline the distinction between itself and its corporate entities, like in the case of the Mercury Energy debacle of 2007 (Roper \& Schoenberger-Orgad, 2011). When power was cut to the home of an Auckland family, resulting in the death of a family member who relied on an oxygen machine to breathe, the Prime Minister publically condemned the responses of the two SOEs involved (Roper \& Schoenberger-Orgad, 2011). Roper and SchoenbergerOrgad (2011) concluded that this distancing effort on the part of the Prime Minister was futile because the government, as owner, was ultimately accountable for its SOEs' absence of social responsibility. In the opinion of one SOE senior executive “when SOEs screw up ... it's like, 'that's the SOE, they're a separate entity' ... But if we announce a new [environmental project], [the Prime Minister will] be there tomorrow," (Luke, 2010, p.148). 
The way that CCOs and similar organisations define themselves, the manner in which they are governed, and the influence of public perception on their accountability surely have implications for CCO recordkeeping. Disassociation from the public sector could impact on any number of CCO activities (Cardow, 2005). It seems reasonable to ask whether a CCO that ardently divorces itself from the public sector is likely to be concerned with recordkeeping for the purposes of public accountability. The propensity of local bodies to exert control over their CCOs conceivably extends into recordkeeping, and although local body management of CCO records most certainly crosses the line between shareholding and management, perhaps it is understandable given the tendency of the public to hold government accountable for the activities of its corporate entities (Bell, 1998). Maybe it is of little matter who is managing CCO records as long as someone is, but the motivations for assuming responsibility could be reinforcing the existing confusion around the status of CCOs. Ostensibly perception might be more influential than legal reality when it comes to governance and accountability of CCOs. Hence, the focus of the study concerns what participants perceived rather than clarifying the word of the law.

\section{Transparency, recordkeeping and information culture}

Hood (2007) proposes that blame-avoiding behaviour by politicians and bureaucrats may present an obstacle to transparency measures such as FOI. It is claimed that blame-avoidance is inherent to political and institutional conduct, likely fueled by the tendency in politics for negative information to overshadow the positive (Hood, 2007). Hood (2007) suggests that responses to FOI could involve failure to create records, or alternatively, creating records that are incomprehensible or impenetrable to outsiders and non-experts. A study into the impact of FOI on English local government had difficulty drawing a conclusion as to whether there had been a negative effect on recordkeeping (Worthy, Amos, Hazell \& Bourke, 2011). While some interviewees felt that the repercussions for not having a record outweighed those for having kept one, there was one example of cessation of 
recordkeeping due to FOI, specifically the practice of commenting on draft reports (Worthy et al. 2011). McDonagh's (2009, as cited in Worthy et al. 2011) survey of Irish local government employees responsible for making decisions on FOI requests found that 65 percent of respondents felt that FOI had led to improved recordkeeping, while 29 percent agreed that FOI had led to non-recording of information.

It is fitting to mention here an example of what could be considered 'impenetrable' information in a CCO setting. The plan for the construction of a sports stadium in Dunedin proposed to achieve funding and debt servicing via a complicated institutional matrix of CCOs owned by the Dunedin City Council (DCC) (Porter, 2011). Outwardly the matrix minimized reliance on ratepayers for funding, however, as a trade-off involved "long-term costs on the ratepayer via bleeding of the city's holding companies, their opportunity costs and mortgage risks," (Porter, 2011, p.54). Though the matrix was publicised through the DCC annual plan, Porter (2011, p.51) argued that for the public, and even councillors, it was "virtually impossible to analyse, interpret and ultimately debate," and therefore compromised transparency, accountability, and decision-making. Whether the information was intentionally opaque was not investigated, but this case underlines information quality as a crucial element of transparency (Hood, 2007). Shepherd, Stevenson and Flinn (2010) are explicit about the importance of information quality for FOI compliance. They found that a number of FOI and recordkeeping practitioners in English local government expressed misgivings about the quality and accuracy of information provided to requestors, and associated this with the state of recordkeeping within the organisation (Shepherd et al. 2010).

Superficially the open government movement sits well with the NPM doctrine of accountability for results and performance (Hood, 1995). But, by creating corporations with private sector values, New Zealand's NPM reforms arguably encouraged a preference for withholding information from the public, so as to 
protect competitive edge and profitability (Government Administration Committee, 2005). In a submission on the effect of the Official Information Act 1982 (OIA) on the operation of SOEs, New Zealand Post argued that the OIA regime was "completely inconsistent with the commercial and operational independence given to State Enterprises under their establishing legislation," (State-Owned Enterprises (Ombudsmen and Official Information Acts) Committee, 1990, p.9). In recent times a Bill that proposed to include port companies under the definition of a $\mathrm{CCO}$ in the LGA, thereby exposing them to LGOIMA, was defeated on the basis that LGOIMA would hinder their efficiency and competitiveness (Local Government (CouncilControlled Organisations) Amendment Bill, 2012). A survey exploring information culture and information use in three Canadian organisations, two private and one public, revealed both a low tendency for external information sharing and low transparency in the private organisations (Choo, Bergeron, Detlor \& Heaton, 2008). Low transparency was interpreted as an indicator of strong commercial drive (Choo et al. 2008).

Until the passage of the LGA and the PRA the public accountability framework for LATEs was limited to an annual statement of corporate intent (Local Government Amendment Act (No.2), 1989). LATEs were otherwise protected from public scrutiny, not being subject to LGOIMA, or provisions for the protection of local archives under Part 17 of the Local Government Act 1974. Coney (1998) remarks on the absurdity of finding herself powerless to access information of public interest from her LATE water provider, despite it being 100 percent owned by her local body. SOEs, although covered by the Official Information Act 1982, were free from legal requirements regarding their archives until 2005 (Public Records Act, 2005). Oliver and Konsa (2012) examined the effect of corporatisation on recordkeeping at the New Zealand Post Office, which was split into three SOEs. Outcomes included the devolution of the central registry, dispersal or disposal of Head Office files, and revision or redundancy of positions with recordkeeping responsibilities (Oliver \& Konsa, 2012). Furthermore, these changes to recordkeeping practice occurred at a 
time when popular management theory decried paperwork and written information as signs of a weak organisational culture (Oliver \& Konsa, 2012).

Presently CCOs are covered by both LGOIMA and the PRA, but their recordkeeping remains understudied. Between 2008 and 2010 Archives New Zealand conducted an annual discretionary survey of local authority recordkeeping (Nielsen, 2010). Amongst other things, the survey interrogated the presence of policies and procedures for assessing PRA compliance, the state of the organisation's recordkeeping programme, the creation and maintenance of records, and access to records over 25 years old (Nielsen, 2010). Yet, it appears that CCOs have consistently been excluded from the sample (Archives New Zealand, 2013). In 2007 a performance audit of public entities' statements of intent and annual reports was conducted by the Controller and Auditor-General (2007), which included a sample of 22 CCOs. Significantly, twelve of the CCOs were found to have set at least some performance targets that were not measureable, while 13 had failed to adequately explain variance between intended targets and actual performance in their annual reports (Controller and Auditor-General, 2007). A documentary analysis of local bodies' long-term plans and annual reports, commissioned by the Department of Internal Affairs (DIA), concluded that information provided about CCOs, especially regarding their financial resources, dividend revenue and value of assets, was variable and often incomplete (Montgomery Watson Harza Consultants, 2009).

Evidence from the literature validates the need for further information concerning the recordkeeping of CCOs. Recordkeeping clearly plays a major role in information quality, accountable reporting and achieving the aims of FOI; areas in which CCOs have exhibited deficiencies (Controller and Auditor-General, 2007; Montgomery Watson Harza Consultants, 2009; Porter, 2011). The combination of corporatisation and changing attitudes toward information has certainly had negative consequences for recordkeeping in comparable organisations (Oliver \& Konsa, 2012). While it is misleading to suggest that all CCOs have a commercial focus that causes reticence in 
information sharing, particularly as many are non-profit organisations, it is fair to question whether their mission, and their history of exclusion from key information management regulations, might have coloured their outlook on transparency and recordkeeping (Choo et al. 2008; Oliver, 2011). Referring back to the first half of the discussion, it is perhaps unsurprising that $\mathrm{CCO}$ recordkeeping has escaped notice thus far given the (mis)perceptions around CCO governance and accountability. 


\section{Research Methodology}

The study used a descriptive research design and its general approach was quantitative. Several of the research questions pointed toward a need for qualitative data, so as to gain richer insight, and this need was accommodated within the chosen method by including several open-ended questions. A wholly qualitative approach was rejected due to the difficulties it would have presented for generalizing findings. Information produced by local bodies about their CCOs suggests that CCOs are highly heterogeneous with regard to their size and activities, so data collected from a small sample could not have been considered representative.

As the study seeks to ascertain variation between cases it was decided to employ quantitative survey research of a cross-sectional design (Bryman, 2012). A survey appeared to be a feasible means of gathering data from local bodies, as the 2010 Archives New Zealand annual survey of local authority recordkeeping had a response rate of 60 percent (Nielsen, 2010). Moreover, local bodies are accustomed to engaging with the public and responding to information requests. In the absence of prior studies the chances of gathering a representative response from CCOs were uncertain. It was unknown what proportion of CCOs employed specialised recordkeeping staff and indeed this was a subject of enquiry for the research. It was anticipated that non-specialised staff might be less motivated to respond to the survey, due to unfamiliarity with the domain of recordkeeping. Nevertheless, it was thought that even if responses from CCOs were poor the local body responses would provide some evidence as to the state of CCO recordkeeping programmes.

The research was conducted on a strictly anonymous basis and informed consent was obtained from participants. It involved human participants so approval was sought from, and granted by, the School of Information Management Human Ethics Committee. 


\section{Population and sample}

\section{Survey population}

The organisation types that made up the survey population were:

- Local bodies that hold a controlling interest in one or more CCOs

- $\mathrm{CCOs}$

- Subsidiaries of a CCO that are at least 50 percent controlled by the CCO

Subsidiaries of CCOs were included because the LGA (2002, Section 6) states that an organisation that is indirectly controlled by a local body is considered a CCO; hereafter, subsidiaries are covered by the term CCO. The survey population comprised 46 local bodies and approximately $200 \mathrm{CCOs}$. The latter figure did not include organisations that were excluded or exempted from CCO status under the LGA (2002, Part 4, Section 6; Part 7) since it was unclear whether such organisations came under the purview of the PRA.

\section{Identifying the sample frames}

Local bodies and CCOs were treated as separate sample frames. There were no existing lists from which to draw a sample so they had to be constructed. It was believed that the most expedient procedure for identifying CCOs would be to request basic information directly from local bodies. To this end an information request was emailed to all local bodies on 29 November 2012 (see Appendix I). Since the information sought was publically available, or discoverable under LGOIMA, human ethics committee approval was not required. The quality of the responses was variable, so it was necessary to both substantiate and supplement the data collected from local bodies by analysing their publications. 
Previous research has established that local bodies typically report on their CCOs in their annual reports, although details can be wanting (Montgomery Watson Harza Consultants, 2009). 2011/2012 annual reports from all local bodies were analysed to discover which of those organisations had CCOs. If the reporting was unclear additional publications were examined, such as long-term council community plans (LTCCPs), local body websites and CCO annual reports or websites. The analysis revealed that local bodies do not consistently specify whether their arms-length organisations have CCO status or whether they have been exempted from CCO status, supporting the findings of Montgomery Watson Harza Consultants (2009). Moreover, the status of CCOs is frequently subject to change, for example, after the survey had been distributed it was discovered that in March 2013 Queenstown Lakes District Council had decided to dissolve two of its CCOs and transfer their functions in-house (Bryant, 2013, March 21). Consequently, some CCOs may have been incorrectly included or excluded from the sample frame. In an effort to remedy this potential coverage error a screening question was included in the survey asking whether the respondent's organisation was exempt from CCO status (Andres, 2012).

\section{Exclusion from the sample frames}

Organisations were excluded from the sample frames if they met the following criteria:

- Local bodies that only had CCOs that had been exempted from CCO status under the LGA.

- Local bodies that only had a minority interest in one or more CCOs. This can occur when multiple local bodies collectively control a CCO.

- CCOs that were dormant or being wound up.

- Organisations that could not be verified as CCOs. 
Thirty-two organisations were excluded from the local body sample frame. 57 organisations were excluded from the CCO sample frame. 26 of those had to be excluded by virtue of their lack of contact information, meaning it would be impossible to distribute the survey to them. The final figures for the sample frames were 46 local bodies and 143 CCOs.

\section{Sample}

For local bodies $\mathrm{N}=$ fewer than 100 , thus common practice dictates that sampling is unnecessary (Leedy \& Ormrod, 2012). A reputable formula for calculating sample size (Dillman, Smyth \& Christian, 2009) was used determine the desirable sample size for CCOs. The margin of error was set at 5 percent, the confidence level at 95 percent and the response distribution at 50 percent, producing a figure of 132 . This number was so close to that of the sample frame that it was decided that sampling of CCOs was also unwarranted.

\section{Data Collection}

\section{Survey Design: General}

The survey was designed using Qualtrics survey software. Because the software provided the functionality to skip or hide questions based on the respondent's answers, it was possible to construct a single survey that both local bodies and CCOs could respond to (see Appendix II). A screen design with one question per page was chosen over a scroll design, as the literature indicates that the latter can result in a higher item nonresponse rate (Vincente \& Reis, 2010). Although researchers have advocated against the inclusion of a progress indicator when a survey takes 20 minutes or more, since this draws the respondent's attention to the end point being remote, one was included in this survey (Matzat, Snijders \& van der Horst, 2009). The time burden of the survey was 10 minutes or less so it was thought that a 
progress indicator could have a beneficial effect on the tendency of respondents to continue participation.

Definitions of non-technical terms were displayed to all respondents at the beginning of the survey, rather than providing the option to request or rollover definitions (Conrad, Couper, Tourangeau \& Petychev, 2006). Research by Conrad et al. (2006) found that respondents were much less likely to request definitions for ordinary terms that they assumed they already understood. The prospective respondents were expected to have their own understanding of terms such as CCO and local authority, but due to the unreliable identification of organisations as CCOs in council publications, and the difference in usage of the term 'local authority' in the LGA versus the PRA, it was decided to convey the intended meaning to all.

It was predicted that respondents' acquaintance with recordkeeping and recordkeeping terminology would be mixed. Consequently, only essential jargon was used, namely the terms "record" and "records management." A brief definition of "record" accompanied by several examples was reiterated at the beginning of each set of records management-focused questions. Feedback from pretesting suggested that more examples of records and record formats should be provided, but it was felt that a lengthier description might deter respondents from reading the definition at all.

The terms "local authority" and "records management" were used throughout the survey, as they were considered more familiar to respondents. However, this report uses "local body" in place of "local authority" so as to avoid confusion with the PRA (2005, Part 4) definition of "local authority," which encompasses CCOs. It also uses the term "recordkeeping" in the Australasian sense, as a "broad and inclusive concept of integrated recordkeeping and archiving processes" (McKemmish, 2001, p.337), in preference to the term "records management," which implies a narrower concept. 


\section{Survey Design: Questions}

The survey preamble contained an information sheet for respondents and a statement regarding consent to participate, as required by the Victoria University Human Ethics Committee (see Appendix II). The survey was divided into three sets of questions: the first two applied to local bodies and CCOs while the third applied only to CCOs. An overall forced-response design was avoided because this has been found to significantly increase dropout rate and generate item response error (Stieger, Reips \& Voracek, 2007). Forced-response was applied to two questions, once to ensure that respondents viewed the correct questions for their organisation type and once as a technical workaround. The survey was pretested with two individuals who were familiar with the subject matter. Minor improvements to question wording were suggested and some were implemented.

Nominal and ordinal levels of measurement were used. Questions that employed a Likert-type scale offered 5 response categories with a "don't know" alternative. Although there is debate about whether the reliability of a Likert-type scale is maximized with 7 or 5 categories, 5 is certainly seen as providing an appropriate level of reliability (Andres, 2012; Lozano, García-Cueto \& Muñiz, 2008). Explicitly offering a "don't know" option is discouraged by some sources, since it has been shown that the proportion of respondents selecting "don't know" increases (DeRouvray \& Couper, 2002). But, uncertain response categories seem to be of most concern for attitude questionnaires, which this survey was not (Derouvray \& Couper, 2002). Moreover, it was anticipated that "don't know" could be a genuine answer for non-specialist respondents. Response options for scalar questions were ordered from positive to negative with "don't know" presented last, so as encourage substantive responses (Stern, Dillman \& Smyth, 2007).

The three sets of questions presented in the survey align with the research questions as follows: 


\section{Set 1: Research Question 3}

The first five categories for organisation type were taken from the LGA. The categories for organisation size were based on preliminary data collected from local bodies (see Appendix I). The categories for CCO business activity were an abbreviated version of the $\mathrm{CCO}$ activities identified in research by Montgomery Watson Harza Consultants (2009).

\section{Set 2: Research Questions 1, 1.1 and 1.2}

Since it was unknown what type of local body involvement in CCO recordkeeping was to be expected it was decided to implement both closed and open questions. The series of items using a Likert-type scale was modelled on questions in the 2010 Archives New Zealand annual survey of local authority recordkeeping (Nielsen, 2010). The final open-ended question in this set was provided to collect qualitative data on the motivations for local body involvement in CCO recordkeeping, as well as barriers to involvement.

\section{Set 3: Research Questions 2 and 2.1}

In order to explore the second research question the qualities of a formal recordkeeping programme had to be defined. Since the research was being conducted in the New Zealand context with organisations that were subject to the PRA, although not to the PRA audit programme, it was judged that Archives New Zealand's (2009) Public Records Act audit self-assessment tool was a fitting model. The tool is described as "translating existing PRA and mandatory standard requirements into attributes of achievement that describe or reflect the expected range of recordkeeping operational practices," (Archives New Zealand, 2009, p.1). Its attributes of achievement are structured into eight areas and are designated as reflecting one of three stages in the passage toward growing recordkeeping capability: initiation, establishment or extending capability (Archives New Zealand, 
2009). Because so little is known about the maturity of CCO recordkeeping programmes it was decided that reproducing the tool in its entirety could be overwhelming for respondents. Therefore, the four questions with a Likert-type scale were based on the first four areas in the tool and their attributes of achievement up to the stage of establishment. Some attributes of achievement were abbreviated or reworded since the level of wording had to be appropriate for nonspecialists (Rea \& Parker, 2005).

\section{Survey Distribution}

A URL link to the survey was distributed via email on 5 April 2013 and the link remained active for 15 days. The text of the invitation to participate (see Appendices III and IV) was fairly long, yet research has shown that a long invitation text does not have a negative effect on response rates, and in some cases may enhance them (Kaplowitz, Lupi, Couper \& Thorp, 2012). Due to the brevity of the data collection period only one follow-up email was sent (see Appendix V), three days before the close date, thanking those who had responded and reminding those who had not.

A preliminary information request sent to local bodies (see Appendix I) obtained direct email addresses for 34 local body records managers and email addresses for contacts in $40 \mathrm{CCOs}$. For a further $16 \mathrm{CCOs}$ it was indicated that a local body records manager was the suitable contact, and in these cases the survey was distributed to the records manager rather than the CCO. For direct contacts the invitation to participate was distributed to multiple recipients using the blind carbon copy field to ensure confidentiality.

For the 12 local bodies that did not provide email addresses for their records managers a personalized email was sent to the local body requesting that the survey be forwarded to the records manager. Considerable effort was expended examining publications to identify appropriate email addresses for the remaining 87 CCOs. According to the PRA the administrative head of an organisation ultimately holds 
responsibility for that organisation's recordkeeping (Public Records Act, 2005). It proved difficult to assemble a comprehensive list of email addresses for administrative heads of CCOs so, as with the records managers, a personalized email was sent to local bodies asking them to forward the survey to specified CCOs.

There was a small amount of non-contact error introduced as a result of three email addresses being invalid. The recipients did not make any enquiries for assistance, although a few of them provided information that helped with distributing the survey directly to CCOs.

\section{Assumptions}

It was expected that all recipients would have Internet access and an adequate Internet connection for viewing and submitting the survey, since they worked in organisational settings. It was also assumed that local body participants would be specialised recordkeeping staff, since 75 percent of local bodies are known to employ such staff (Nielsen, 2010).

\section{Data Analysis}

Descriptive statistical techniques were used for data analysis. Non-parametric tests were judged to be incompatible with the data, for example, the chi-square test could not be applied to cross-tabulations since the expected frequencies were consistently below 5 and it was not logical to merge categories in order to boost them (Levin \& Fox, 2011). 


\section{Results}

\section{Responses and respondents}

A total of 41 completed responses were received, 12 of which were prompted by the reminder email. Two people began the survey but did not complete any questions. These responses were therefore invalid and were discounted from the response rate calculations and data analysis. The survey completion rate was 95 percent. Figure 1 gives a breakdown of respondents by organisation type, showing that 23 respondents participated on behalf of a local body, while the remaining 18 represented CCOs. The response rates were 50 percent for the local body sample and 12.59 percent for the CCO sample. No respondents identified themselves as answering on behalf of a subsidiary of a CCO. Three responses were ineligible for inclusion in the study, one because the organisation was exempt from CCO status under the LGA, and two due to the local body having no CCOs.

\section{What type of organisation are you responding on behalf of?}

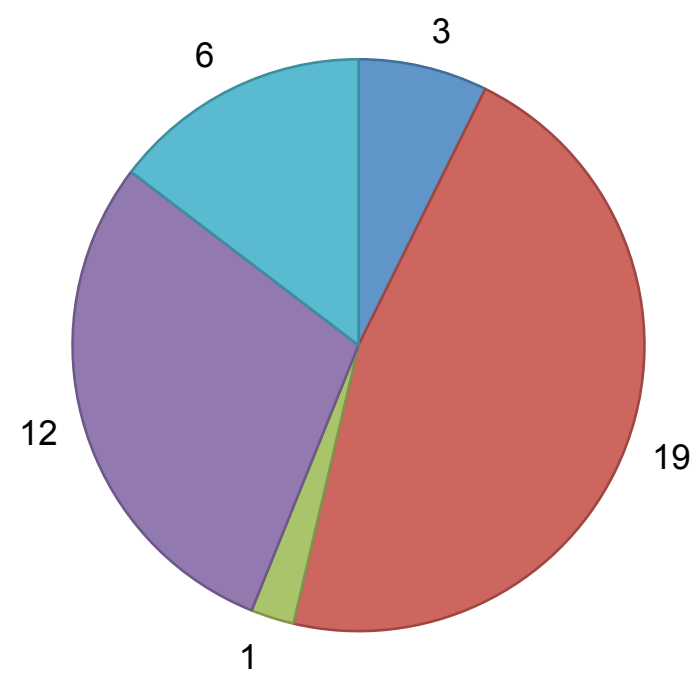

-Regional council

-Territorial council

$\square$ Unitary Council

$\square \mathrm{CCO}$

$\square$ ССТO

Figure 1: Frequency of organisation types represented in the dataset 
Eighteen local body respondents (78.26 percent) came from organisations with 100-500 staff. Twelve CCO respondents came from organisations with 50 or fewer staff, while 13 said that their organisation had one controlling local body.

\begin{tabular}{lll}
\hline $\begin{array}{l}\text { Number of } \\
\text { unanswered items }\end{array}$ & Local body respondents (\%) & CCO respondents (\%) \\
\hline 1 & $43.48 \%$ & $72.22 \%$ \\
2 & $8.70 \%$ & $44.44 \%$ \\
3 & - & $27.78 \%$ \\
More than 3 & - & $5.56 \%$ \\
\hline
\end{tabular}

Table 1: Item-level nonresponse rates per number of unanswered items

Table 1 summarises item-level nonresponse rates for local body and CCO respondents. In all, 23 respondents (56.10 percent) skipped one or more open questions, while three respondents (7.32 percent) skipped one or more closed questions. One local body respondent advised that due to the choice of scale they had difficulty providing a meaningful answer to the question "In what ways is your organisation involved with the records management programme(s) in its CCOs and/or CCTOs." This was because their organisation had multiple CCOs and its level of involvement in recordkeeping varied greatly from one to another.

\section{Are local bodies involved with CCO recordkeeping programmes?}

As illustrated by Figure 2 more than half of local body and CCO respondents answered in the affirmative for local body involvement with CCO recordkeeping. Twelve out of 21 local body respondents (61.90 percent) stated that the organisation was involved with recordkeeping in some or all of those CCOs. Two other local body respondents said that their organisations were not involved but revealed some contact or possible future involvement in the open comments. Ten out of 16 CCO respondents (62.50 percent) stated that there was local body 
involvement in the organisation's recordkeeping programme. One CCO respondent did not answer the question.

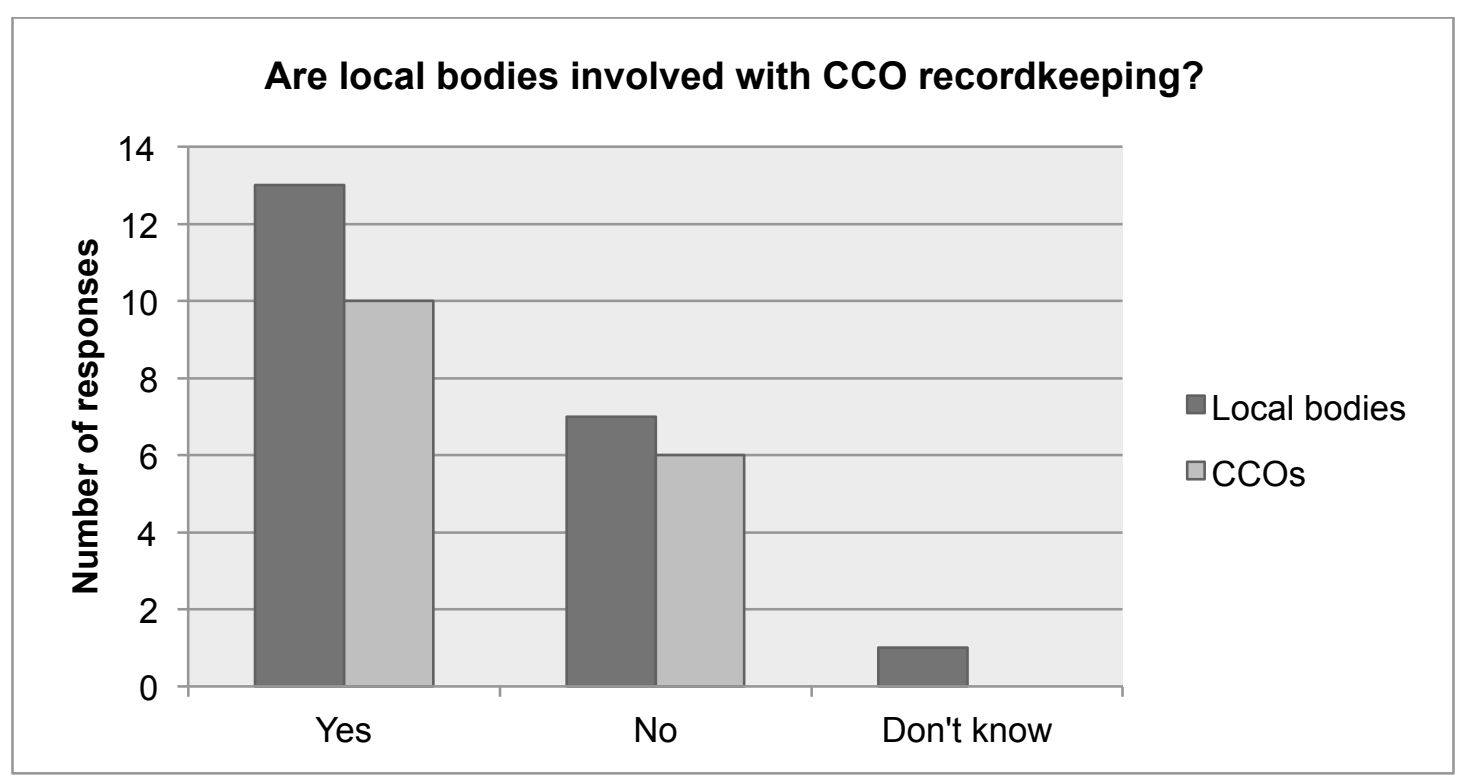

Figure 2: Frequency of local body involvement with CCO recordkeeping according to respondents

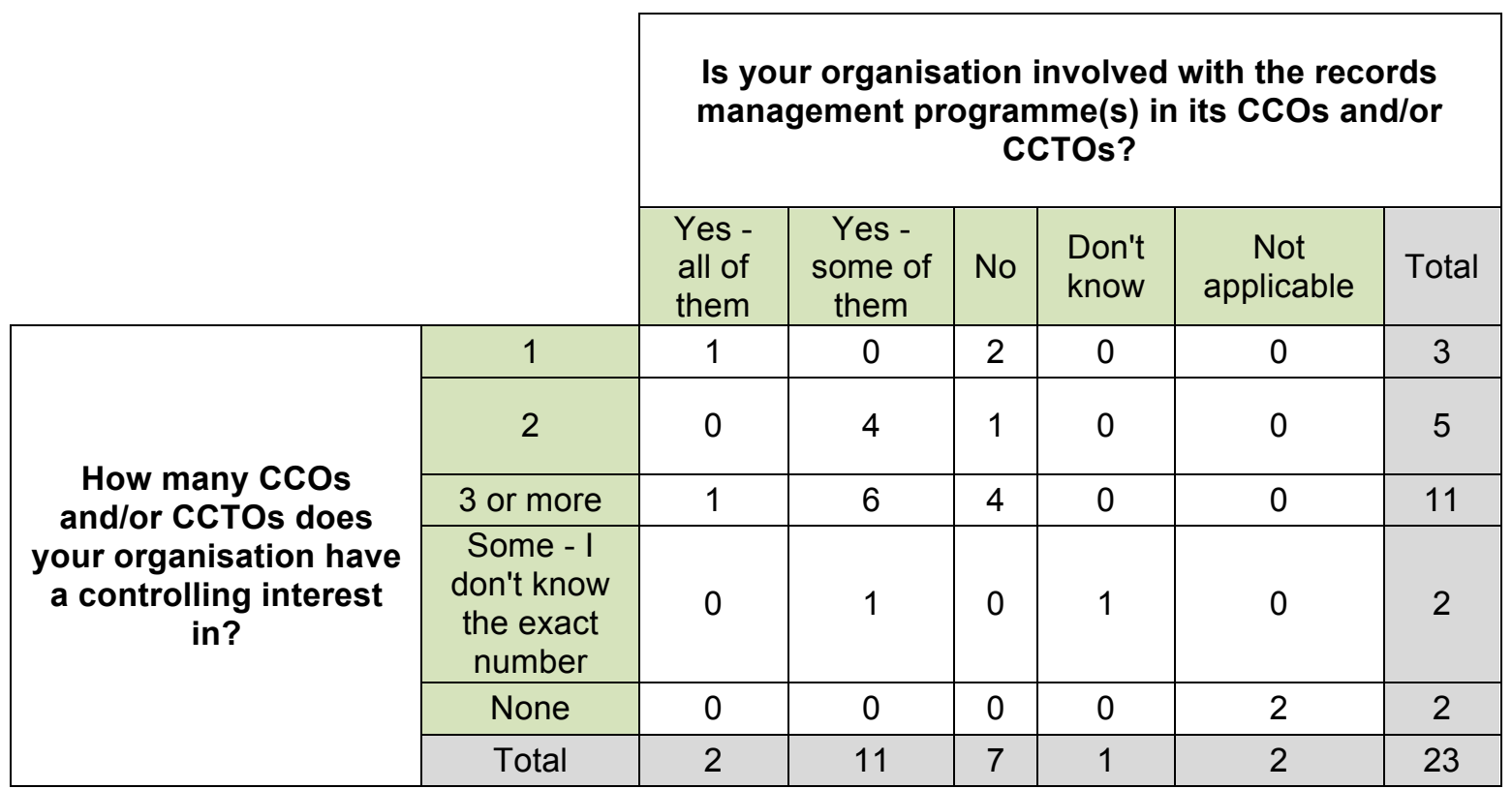

Table 2: Cross tabulation of the number of CCOs controlled by a local body with local body involvement in CCO recordkeeping 
Table 2 provides a further breakdown of the local body responses presented in Figure 2, showing that two local body respondents selected "Yes - all of them," while 11 selected "Yes - some of them." It also compares involvement in CCO recordkeeping with the number of CCOs a local body controls.

\section{If local bodies are involved in CCO recordkeeping programmes, to what extent?}

Ultimately 13 local body and 10 CCO respondents were eligible to answer statements about the extent of local body involvement in CCO recordkeeping programmes. Figure 3 demonstrates the frequency with which each type of involvement occurs from the local body perspective. Some of the scale points were merged together, as they were not substantively different and there was minimal risk of obscuring findings. The statements presented to respondents, with slight variations on wording to fit the audience, were as follows:

1. Local body recordkeeping staff members provide CCOs with advice.

2. CCOs' paper records are managed in systems administered by a local body.

3. CCOs' electronic records are managed in systems administered by a local body.

4. CCOs have adopted local body recordkeeping policies.

5. CCOs have adopted local body recordkeeping procedures.

6. Staff members from CCOs participate in a local body's recordkeeping training programme.

7. CCOs transfer records that have continuing value (i.e. archives) to a local body.

According to 11 out of 13 local body respondents (84.62 percent) the provision of recordkeeping advice to $\mathrm{CCOs}$ and the transfer of $\mathrm{CCO}$ archives to the local body happen at least sometimes if not more regularly. For 12 out of 13 respondents the majority of answers to the 7 statements fall into the "Sometimes," "Rarely" or 
"Never" categories. Under "Other" one respondent said "For some [CCOs] the records are managed totally within the council's EDRMS, for others there is no direct involvement ... in recordkeeping, and several variations in between."

For the same set of statements CCO responses largely lean toward the positive end of the scale, that is, sometimes or more frequently. Eight out of 10 respondents said that the transfer of archives occurs all of the time or often. Under "Other" two CCO respondents stated that their organisation contracts its local body to manage financial records only.

Five out of 13 local body respondents and four out of $10 \mathrm{CCO}$ respondents have formal agreements, or are developing formal agreements regarding local body involvement with CCO recordkeeping. One of the local bodies has formal agreements with some of its CCOs but not with others.

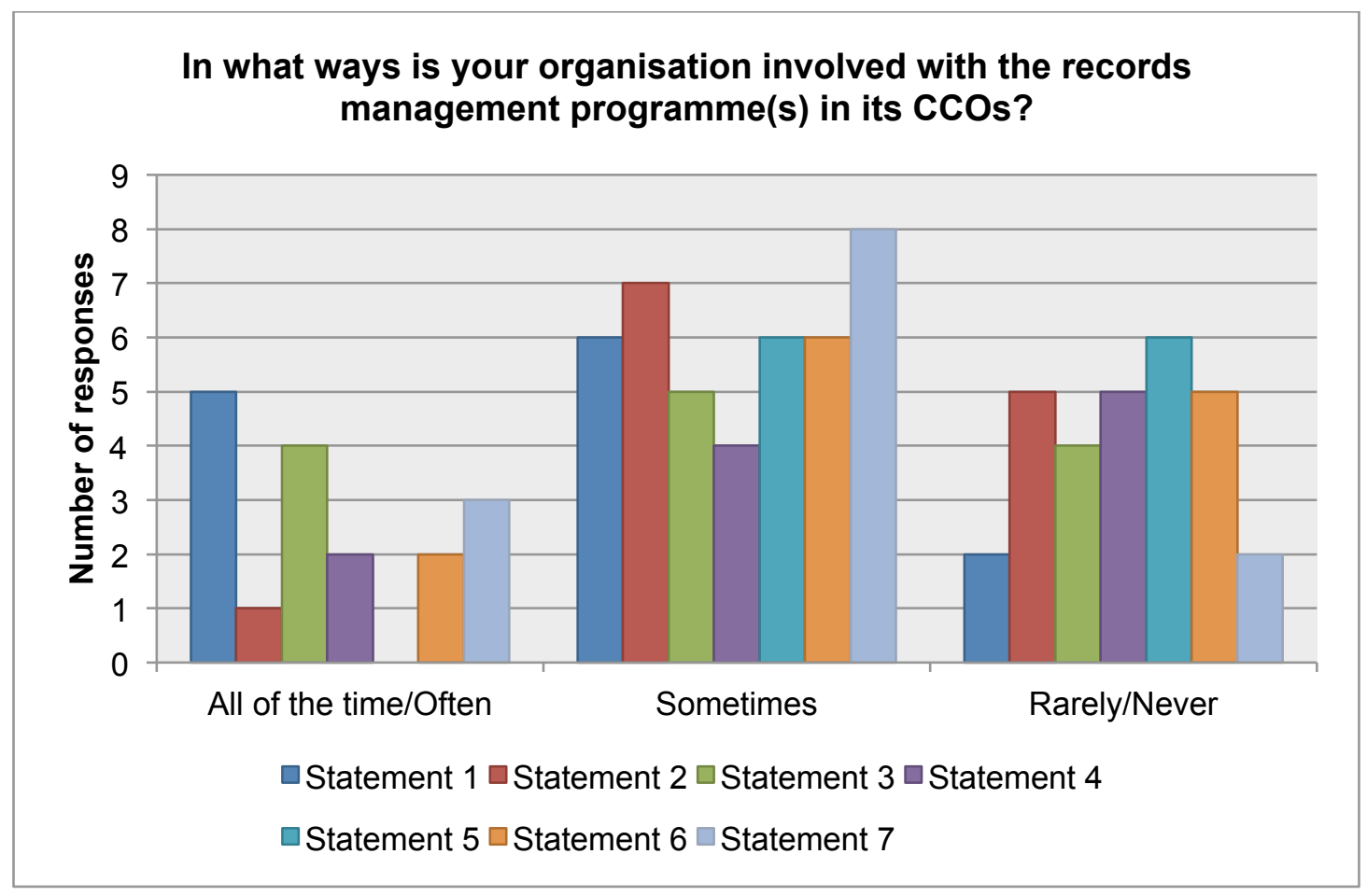

Figure 3: Perspective of local body respondents on their organisation's involvement in CCO recordkeeping 


\section{What motivates local body involvement and what are the barriers to local body involvement?}

All local body respondents, except those without CCOs, were asked to comment on why their organisation was or was not involved with recordkeeping programmes in its CCOs. Fifteen comments were received and the following themes were identified in the qualitative data:

1. Lack of clear guidance or decision-making about responsibility for CCO recordkeeping or level of local body involvement required.

Four respondents cited this reason for not being involved with recordkeeping programmes in their CCOs. Some specified where the direction, guidance and decision-making had failed to come from, such as senior management. In one case the organisation's largest CCO was jointly owned with another local body and when the CCO was established "no decision was made as to which council would monitor/manage recordkeeping."

2. Lack of resources.

Three respondents noted a shortage of local body resources for managing CCO recordkeeping. One of them stated that their main CCO wanted the local body to manage its physical records, but the local body lacked the resources to do so. Another of them remarked that having a poor Internet connection impeded full involvement in CCO recordkeeping.

\section{Resistance from CCOs.}

Two respondents commented on the attitude of their CCOs toward recordkeeping legislation and local body involvement in recordkeeping, for example, "Our main 
CCO seems to think it does not have to comply with the PRA," and "[The CCO is] ignoran[t] of legislative requirements."

\section{Ownership of CCO records}

Several respondents suggested that their organisations owned CCOs' records, for example, "All [CCO] records are owned by the Council, however the management of them is the responsibility of the CCO," and "[They have a] territorial attitude towards 'their' records." However, another person said, "All our CCOs and CCTOs take responsibility for their own records."

\section{Other observations}

One person described one of its CCOs as "an internal CCO so [it] comes within the Councils [sic] normal processes." Four respondents indicated that their organisations only manage records created through interactions with CCOs.

All CCO respondents were given the opportunity to include further comments about the level of local body involvement in their recordkeeping. One person remarked, "This contract [with the local body] assists us to meet NZ Audit standards with a minimum of staff." Three respondents who said there was no local body involvement in their recordkeeping, and so were not presented with the statements listed in the previous section, provided comments. Two mentioned that they transferred legacy records or archives to their local body, with one of them adding that the local body did "not have any input into what files are archived." The third said that their local body did "assist with major issues if asked." 


\section{Are formal recordkeeping programmes being implemented in CCOs?}

Seventeen CCO respondents qualified to answer 25 statements concerning their organisations' recordkeeping activities. There was a 100 percent item-level response rate, with four “Don't know” responses spread across Statements 8, 9 and 10. The statements presented to respondents and the main findings for each activity type were as follows:

Planning activities

1. There is a senior manager who sponsors records management.

2. Systems (both paper and electronic) that create records have been identified.

3. Systems (both paper and electronic) that manage records have been identified.

4. There are formal records management policies.

5. There are formal procedures for creating and filing paper records.

6. There are formal procedures for creating and filing electronic records.

7. Records that are critical for the functioning of the organisation are identified.

8. There is a disaster recovery plan for records.

9. New business systems are designed to incorporate records management requirements.

10. There is a current records management plan or strategy.

For Statements 2, 3, 4, 6 and 7 the answers lean heavily toward the positive end of the scale ("Definitely yes" or "Probably yes"). Overall, for each of the statements regarding planning the majority of respondents selected "Partially," "Probably yes," or "Definitely yes."

Resourcing activities

11. Records management roles are documented. 
12. Records management responsibilities are documented.

13. Records management responsibilities are communicated to staff.

14. Specialised records management staff are appointed.

For the resourcing activities 11 out of 17 respondents (64.71 percent) replied that their organisation had probably not or definitely not appointed specialised recordkeeping staff. There was a fairly even distribution between positive and negative answers to the other three statements about resourcing.

\section{Training activities}

15. The records management training needs of records management staff have been identified.

16. The records management training needs of all other staff have been identified.

17. Records management staff are responsible for defining records management training requirements.

18. There is a records management training plan.

19. Staff receive records management training.

For all of the training activities there was a moderate lean toward the negative end of the scale ("Probably not" or "Definitely not"). The majority of responses to Statement 18 fell into the "Partially" and "Definitely not" categories.

Monitoring and reporting activities

20. Records management reporting requirements are documented.

21. Records management staff monitor records management practices.

22. Records management staff report on records management practices.

23. The results of monitoring are reported to the appropriate level of management. 
24. The creation of records is routinely monitored.

25 . The capture of records in systems is routinely monitored.

Overall, for each of the statements regarding monitoring and reporting the majority of respondents selected "Partially," "Probably not," or "Definitely not."

In the open comments one respondent mentioned that their organisation was "in the process of completing our PRA 2005 compliance requirement[s]." A person from an organisation with less than 10 staff said, "We have a records policy, but procedures are not necessarily in written form."

\section{If not, what are the reasons behind this?}

For seven CCO respondents the majority of answers to the 25 statements about their recordkeeping programmes, referred to in the previous section, lie in the "Probably not" or "Definitely not" categories. All seven come from small organisations of 50 or fewer staff and none of them have specialised recordkeeping staff in their organisations. Only three have local body involvement in their recordkeeping. Two people remarked on their size and what implications this had for their recordkeeping:

This company is very small, utilises Council resourse [sic] and is reliant on Councils [sic] record management systems, it does not have any records management systems, policies or procedures of its own (Respondent 1 ).

Being only small most communications etc [sic] are just kept on [the] computer [they are] written on (Respondent 2).

In comparison, of the six CCO respondents who answered "Definitely yes" or "Probably yes" to more than half of the 25 statements, five come from organisations with 50 or more staff and four have specialised recordkeeping staff. 
Six CCO respondents have no local body involvement in their recordkeeping. Of those, the two that do have specialised recordkeeping staff in their organisation replied "Definitely yes" to 92 percent and 84 percent, respectively, of the 25 statements. Figure 4 displays the frequency with which the other four, who did not have specialised recordkeeping staff, selected each of the scale points compared with the size of their organisations. Only the respondent whose organisation had 50-100 staff answered "Definitely yes" or "Probably yes" to the majority of the statements.

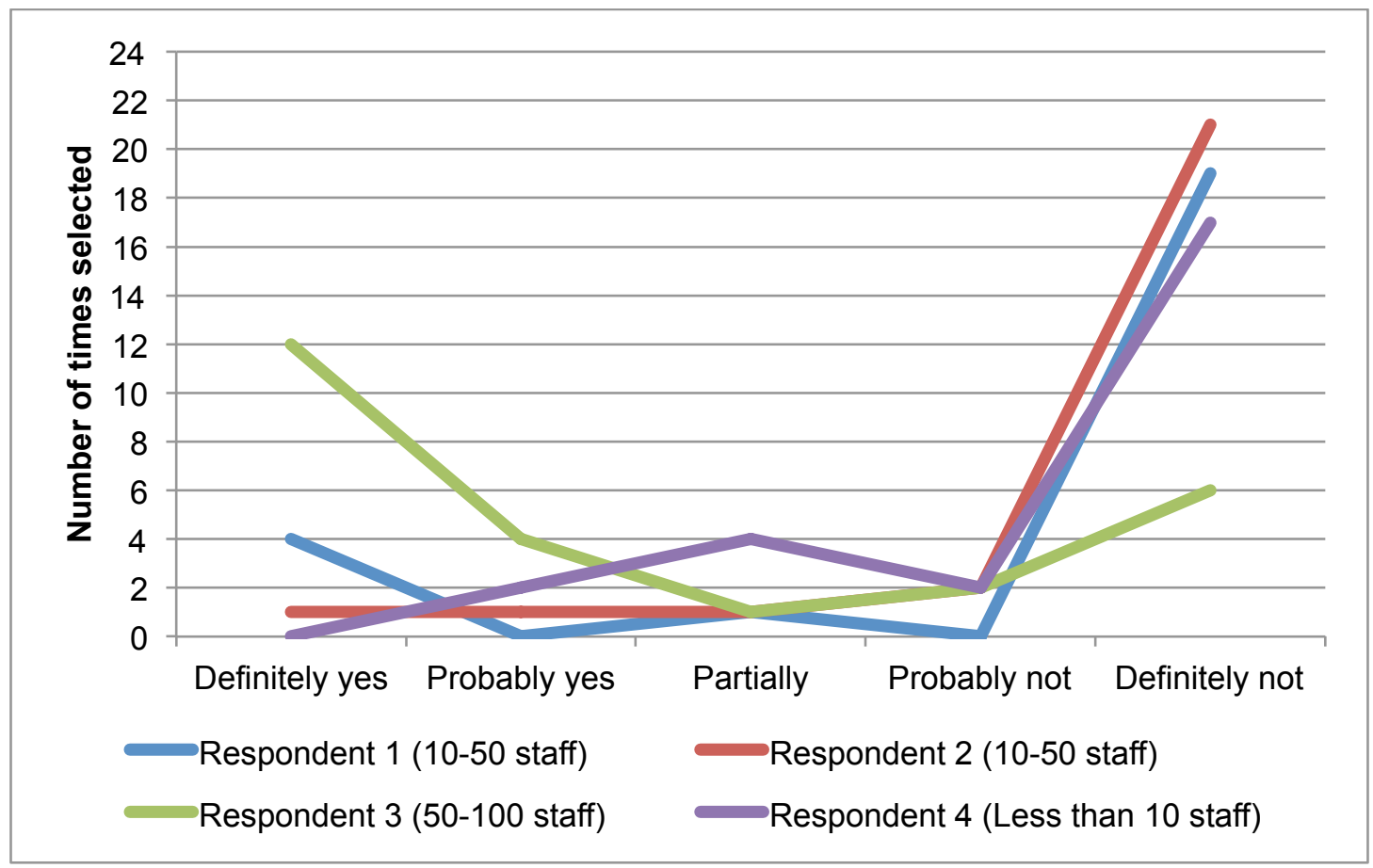

Figure 4: CCO respondents with no local body involvement in their recordkeeping and no specialised recordkeeping staff

\section{Do the organisation size, type of CCO or type of local body have any influence the other research questions?}

It is unclear whether there is a causal relationship between the size or type of local body, or size of CCO, and local body involvement with CCO recordkeeping. Though 
the response rate for local bodies was 50 percent it cannot be stated with certainty that there is no relationship between size or type of local body and involvement with CCO recordkeeping. This is because the number of responses is too small to use the chi-square operation. The link between CCO size and the presence of a formal recordkeeping programme is discussed in the previous section. There were too few CCO responses to make any inferences about the effect of industry sector on the presence of formal recordkeeping programmes in CCOs. 


\section{Discussion}

\section{Responses and respondents}

There was a good response rate from local bodies, indicating that for them CCO recordkeeping is a salient issue. Fifty percent of the local body sample participated in the survey, which compares favourably with mean response rates for the distribution method (54.7 percent for email distribution) and for the sector (54.5 percent for the public sector) in an organisational study (Baruch \& Holtom, 2008). The completed sample also looks to be fairly representative of the survey population in terms of the size of the respondents' organisations. Thirty organisations out of the 46 in the survey population (65.22 percent) have 100-500 staff (Department of Internal Affairs, 2011), while in the completed sample 78.26 percent of respondents come from organisations with staff numbers in that size bracket. Responses were distributed across all size brackets, although organisations with "Less than 50 staff", "500-1000 staff" and "More than 1000 staff" were slightly underrepresented. It is possible that the 50 percent of the local body sample who did not reply have no involvement with CCO recordkeeping programmes, and so thought that their contribution was unwanted, but the email invitation attempted to overcome this perception (see Appendix III). It is therefore acceptable to extrapolate the local body data with some confidence to the entire local body population.

It was anticipated that the CCO response rate would not be as high as for local bodies. There is no pre-existing data to show how many CCOs employ specialised recordkeeping staff, and it was expected that non-specialised staff would be less motivated to participate. The response rate for CCOs was indeed low, at 12.59 percent. Several local body respondents mentioned that their CCOs are unaware of legal recordkeeping requirements, see them as inapplicable, or view them as the local body's problem. We do not know if this is typical of the wider CCO population, 
but it could be a cause behind the shortage of CCO interest in the survey. Twelve of the participants came from small organisations with 50 or fewer staff, but because of the lack of publically available data on the size of CCOs it cannot be established whether this is representative. The work undertaken to identify the sample frame found that approximately $20 \mathrm{CCOs}$ are controlled by multiple local bodies, yet only three of them participated in the study. No CCO respondents were associated with a subsidiary of a CCO, causing one to ponder how applicable recipients from subsidiaries thought the study was to them. Though it is inappropriate to try and generalise the data collected from CCOs to the whole CCO population they do provide some noteworthy insight. Moreover, because there was a good response from local bodies we can come to some meaningful conclusions about CCO recordkeeping using their data.

\section{Are local bodies involved with $\mathrm{CCO}$ recordkeeping programmes?}

The findings reveal that the majority of local body participants (61.90 percent) have some degree of involvement with CCO recordkeeping programmes. The ratio of CCO respondents with local bodies who are associated with their recordkeeping programmes, at 62.50 percent, outwardly corroborates well with the figure for local body respondents, but as previously mentioned it cannot be generalised. The comments of several local body participants suggest that even where local bodies are not connected with CCO recordkeeping programmes there may be some contact or consideration of future association. For example, "At present we have had no involvement with the records side except to advise them that they are governed by the PRA," and "The CCO has only recently been established ... [but] it is anticipated that in time their records will form part of our EDRMS."

Conversely, two local body respondents said their organisations had no CCOs, while one other knew that their organisation had CCOs but not how many, nor whether it was engaged with CCO recordkeeping programmes (see Table 2). It is conceivable that the participants with no CCOs were ineligible for inclusion, yet great effort was 
made to accurately identify local bodies with CCOs. Hence, these data could imply that some local body recordkeepers have low awareness of CCOs. In truth, due to the anonymity of the survey it is impossible to verify whether the respondents who specified that their organisations did have CCOs were aware of the accurate number. Related to this observation, one survey recipient advised me via email "this Council does not have any significant CCOs so the survey is not relevant to us." The concept of a CCO being insignificant hints at one reason why CCOs might escape the attention of local body recordkeepers.

\section{If local bodies are involved in CCO recordkeeping programmes, to what extent?}

The survey instrument adequately captured the different kinds of association one might expect from a local body (see Appendix II), judging by the infrequency of comments about other kinds. It is clear that the instrument forced some local body participants with multiple CCOs to generalise about their involvement, thus obscuring the variation in how they engage with one CCO versus another. In the words of one respondent, "the previous question was difficult to anser [sic] meaningfully as the form of support for RM varies between CCOs." However, of the 16 individuals whose organisations had multiple CCOs only one indicated that the organisation was engaged with recordkeeping in all of them (see Table 2), so perhaps this problem need not be overstated.

Looking at local body responses there is a trend toward occasional or infrequent association, rather than absolute (see Figure 3). The most basic level of participation is centred on advice and the transfer of archives, with the data collected from CCOs supporting this. The open comments provide further insight into how the exchange of advice comes about and whether local bodies determine which records are transferred to them as archives. One local body respondent stated, "We have offered advise $[s i c]$ both verbally and in writing but it has largely being [sic] ignored," implying unsolicited advice and an active role. A CCO respondent, from an 
organisation with no specialised recordkeeping staff, remarked that their local body holds the CCO's archives but does "not have any input into what files are archived," while another said that their local body "assist[ed] with major issues if asked," suggesting that the local bodies play a passive role. Though little explored in this study there is obviously diversity in the character of local body involvement.

Considering the evidence presented in Archives New Zealand's most recent survey of local authority recordkeeping (Nielsen, 2010), local bodies may often be well positioned to store and manage CCO archives, especially where CCOs are small or lack recordkeeping expertise. However, the finding that several local body respondents may see their organisations as owning CCO records, and that where local bodies are involved in CCO recordkeeping programmes over half of the time there is no formal agreement documenting expectations, raises a possible issue with the practice of transfer. Unless a CCO formally agrees that a local body owns its records surely, as an independent organisation, it retains ownership. If there is no agreement and both parties believe that they are the rightful owners of CCO records then discord in the relationship between local body and CCO could occur. This potential for discord is not restricted to CCO archives; the majority of both local body and CCO participants indicated that sometimes, if not more often, CCO records were managed in systems administered by the local body. To further complicate matters, some of those records could well contain intellectual property (Taylor, 2010) or commercially sensitive information that the CCO does not wish to share with the local body (Lineham, 2010). The survey instrument did not interrogate whether rights with regard to CCOs' archives or records are formally agreed upon, so the preceding observations are merely speculation. But given the history of thorny relationships between local bodies and their CCOs, as discussed in the literature review, it is justified speculation.

Revisiting the question of $\mathrm{CCO}$ awareness of legal recordkeeping requirements, it is worth noting that two CCO respondents specified that local body involvement is 
restricted to their organisations' financial records. One of them explained that the agreement they have with their local body "assists us to meet NZ Audit standards with a minimum of staff." One could interpret these data as an indication that some CCOs have a narrow concept of what a record is and only a limited awareness of statutory recordkeeping obligations. Alternatively, they could represent a deliberate concentration of compliance efforts toward records produced by business functions, like financial management, that are subject to heavy public scrutiny. Although Audit New Zealand has the power to assess a CCO's non-financial information for legislative compliance, it appears that financial statements and statements of service performance take centre stage in the public sector annual audit process (Audit New Zealand, 2012). If auditing is a stimulus for these two small CCOs to ensure the proper management of their financial records, then one has to wonder if the absence of audit requirements for CCOs under the PRA affects the power of the Act to encourage CCO concern for the management of other records.

\section{What motivates local body involvement?}

It was earlier posited that the motivation behind local body engagement with CCO recordkeeping programmes could be partly driven by a confused notion of what it means to have a controlling interest in a CCO. Based on the remarks of local body respondents this looks to be true. Misperceptions are arguably present in the statements concerning local body ownership of CCO records and in comments about the status of CCOs, for example, "They appear to think they are a separate identity and do not have to comply with our policies and procedures around records." The belief that the local body has rights and responsibilities with regard to CCO recordkeeping resulting from ownership is apparently a motivating factor for some local bodies. The issue of to what degree CCOs are separate from local bodies may be no clearer for local body recordkeepers than it is for councillors (Bell, 1998; Howie, 2012). If we take the position that a CCO is a discrete organisation that owns its records, then one can foresee CCOs pushing back against local bodies that espouse the aforementioned views and attempt to involve themselves in CCO recordkeeping 
programmes. Though unsupported by the data, it is reasonable to conjecture that resistance from CCOs is a reason why so few local bodies are associated with recordkeeping in all of their CCOs.

It is unsurprising that local body recordkeepers might develop misperceptions about CCOs when superficially some CCOs do not seem particularly independent. One CCO respondent described their organisation as "very small, utilises Council resourse $[s i c]$ and is reliant on Councils $[s i c]$ record management systems," while a local body respondent said that one of its CCOs was "an internal CCO so [it] comes within the Councils $[\mathrm{sic}]$ normal processes." Of the eight CCOs in the dataset with less than 10 staff only one has no local body participation in its organisation's recordkeeping programme, though as previously mentioned two of the eight referred to financial recordkeeping only. These findings suggest that the small size of a CCO is a plausible motivating factor for local body involvement, but due to the low number of CCO responses a statistical correlation cannot be established.

\section{What are the barriers to local body involvement?}

A commonly cited barrier to local body engagement with CCO recordkeeping programmes was an absence of clear guidance or decision-making about responsibility and level of involvement required, which substantiates my own motivation for investigating CCOs. One respondent said that there had been a failure on the part of their organisation and another local body to decide which of them should take responsibility for recordkeeping in a jointly owned CCO, underlining how complicated the question of responsibility for CCO recordkeeping could become. A jointly owned CCO might use the recordkeeping systems of one local body to manage records produced for other local bodies, a possibility that reinforces the need for $\mathrm{CCO}$ recordkeeping to be formally agreed upon by all interested parties.

While several local body respondents apparently felt that their organisations or CCOs should be providing direction, others did not specify from where they thought 
guidance should originate. It would be instructive to know what advice Archives New Zealand has provided to local bodies regarding responsibility for CCO recordkeeping. I am of the opinion that there may not be a legal responsibility for local bodies to take part in CCO recordkeeping programmes, but there are certainly practical reasons for doing so. The study shows that CCOs are among the smallest organisations covered by the PRA. It also provides some insight into recordkeeping within small CCOs that have no local body involvement and no specialised recordkeeping staff, such as the data presented in Figure 4, or the following statement:

Being only small most communications etc [sic] are just kept on [the] computer [they are] written on. Back up does happen from time to time but nothing on a formal basis. Things like drawings of projects are kept by us but not formally stored. If we lose [a] management contract much of this stuff will be lost with us unless we feel generous and do some sor[t] of handover of what we have and know in our heads.

Seventy-five percent of local bodies have specialised recordkeeping staff (Nielsen, 2010) and there is a pre-existing connection with CCOs due to ownership, making them strong candidates for offering the expert guidance such CCOs could benefit from. Besides which, the status of CCOs is changeable, they can be dissolved or reintegrated into local bodies (Bryant, 2013; "Ending of tourism," 2012) so local body recordkeepers could end up managing their records anyway, in which case a prior relationship is surely advantageous. Finally, as suggested by the literature review, if a CCO's recordkeeping comes under public scrutiny and shortcomings are identified, there is a likely risk that the media and ratepayers will hold the local body accountable, regardless of the legal reality.

An additional barrier to involvement identified in the respondents' comments was inadequate resourcing. One can imagine that if there is no guidance or agreement on 
what is expected of local bodies there might be less incentive for them to try and stretch resources to cover CCOs. To look at it from another angle, without firm guidance on who is responsible for what, under-resourced local bodies could be in a weak position for resisting CCOs that assume the "it's your problem, not mine," attitude, as one respondent put it. That said if a definite decision were made that relieved local bodies from legal responsibility for CCO recordkeeping, perhaps it would encourage overstretched local body recordkeepers to avoid or cease providing assistance to CCOs, which may not be a desirable outcome.

\section{Are formal recordkeeping programmes being implemented in CCOs?}

It cannot be claimed that the findings about recordkeeping programmes in CCOs are typical of the survey population, so they will not be discussed in great detail. However, a few thought-provoking observations can be made, particularly concerning what distinguishes organisations that exhibit the attributes of a formal recordkeeping programme from those that do not. The respondents whose organisations show signs of both initiating and establishing an increase in recordkeeping capability (Archives New Zealand, 2009) are mostly larger in size, with their own specialised recordkeeping staff. In contrast, the respondents whose organisations replied in the negative to over half of the statements about their recordkeeping activities were small and had no expert recordkeeping staff.

\section{Do the organisation size, type of CCO or type of local body have any influence on the other research questions?}

Staying with the observations from the previous section, this is a fitting place to look back on the third research question and the subject of organisation size. It is not improbable to suggest that a large $\mathrm{CCO}$, here defined as having 50 or more staff, is in a better position to fund or justify employing a staff member dedicated to recordkeeping than a $\mathrm{CCO}$ with fewer staff, and that the presence of such a staff member bodes well for the maturity of the organisation's recordkeeping 
programme. Indeed, the respondent who made the only mention of working toward PRA compliance was from a large CCO with specialised recordkeeping staff. The idea, introduced earlier, of a CCO being insignificant prompts one to ask whether recordkeeping might be better established in larger CCOs in part because they are considered more important.

\section{Limitations}

The data collected from CCOs cannot be extrapolated to the entire CCO population due to the low response rate. The diversity of local government structures worldwide limits the generalizability of the findings beyond New Zealand. 


\section{Conclusion}

The principal contribution of this study to recordkeeping practice is its documentation of actual and potential issues with CCO recordkeeping that deserve further attention or resolution. Both local body recordkeepers and CCOs undoubtedly require additional guidance on their legal rights and responsibilities toward CCO records, as they may each be operating under a set of false assumptions. It would be well worth seeking the opinion of Archives New Zealand on this matter. Local body involvement in CCO recordkeeping is surely apt and, for some CCOs, essential even, but expectations and rights need to be clearly stated, documented and agreed upon by all interested parties. Not all CCOs have a relationship with local body recordkeepers so official advice and outreach that targets their specific recordkeeping needs seems warranted. Though CCOs should not be absolved from legal recordkeeping obligations it is time to consider the practicalities of applying the PRA to this large and diverse group of organisations. More widely, it is hoped that the study will encourage discussion about the degree to which local government observance of the PRA is monitored, and inform the practice of corporatising government activities.

The study is at the forefront of research into CCO recordkeeping and as such it possibly raises more questions than it provides answers. It does not offer conclusive evidence that CCOs' records are being managed to support open government. A representative study of CCOs and their subsidiaries, exploring their view of legal recordkeeping requirements, the barriers they face to implementing formal recordkeeping programmes, and the assistance they require, is therefore advisable.

Qualitative research, probing what determines local body involvement in CCO recordkeeping programmes, the character of participation, and how the views of local bodies and their CCOs align or diverge regarding involvement, would enrich the findings. An examination, perhaps through case studies, of how the complexities of custody and ownership of CCO records are negotiated could be of benefit to local 
body recordkeepers. Lastly, while preparing to conduct the research it became obvious that there is a lack of transparency regarding which arms-length organisations in local government have CCO status. This situation could be remedied by the establishment of a public register of CCOs, perhaps hosted by the Department of Internal Affairs, or the inclusion of a requirement to specify CCO status in the New Zealand Companies Register and the registers for societies and trusts.

\section{Acknowledgements}

Special thanks to Dr Gillian Oliver for her advice and support. 


\section{References}

Andres, L. (2012). Designing and doing survey research. London, United Kingdom: SAGE Publications Ltd.

Archives New Zealand. (2009). Public Records Act audit tool. Retrieved May 22, 2013, from: http://archives.govt.nz/public-records-act-audit-self-assessment-tool

Archives New Zealand. (2011). Glossary of Continuum definitions - R. Retrieved August 19, 2012, from: http://archives.govt.nz/advice/continuum-resourcekit/glossary/continuum-definitions\#R

Archives New Zealand. (2013). Government recordkeeping surveys. Retrieved January 14, 2013, from http://archives.govt.nz/advice/public-records-act-2005/compliancetools/government-recordkeeping-surveys

Audit New Zealand. (2012). What to expect from your audit. Retrieved May 28, 2013, from http://www.auditnz.govt.nz/public-sector-auditing/publications-resources/publicsector-auditing/what-to-expect-from-your-audit

Baruch, Y. \& Holtom, B.C. (2008). Survey response rate levels and trends in organizational research. Human Relations, 61(8), 1139-1160.

Bell, I.B. (1998). Local authority trading enterprises (LATES): Issues of governance and accountability. Unpublished Master of Public Policy research paper, Victoria University of Wellington, Wellington, New Zealand.

Boston, J., Martin, J., Pallot, J. \& Walsh, P. (1996). Public management: The New Zealand model. Auckland, New Zealand: Oxford University Press. 
Bryant, G. (2013, March 21). Lakes plug pulled on council entities. The Southland Times. Retrieved from http://www.stuff.co.nz/southland-times/news/8452574/Lakesplug-pulled-on-council-entities

Bryman, A. (2012). Research designs. In Social research methods (4th ed.) (pp. 44-78). New York, United States: Oxford University Press.

Cardow, A.G. (2005). The construction of entrepreneurship in publicly-owned utilities in New Zealand: Local and translocal discourses, 1999-2001. (Unpublished doctoral thesis, University of Otago, 2005). Retrieved from http://hdl.handle.net/10523/3643

Choo, C.W., Bergeron, P., Detlor, B. \& Heaton, L. (2008). Information culture and information use: An exploratory study of three organisations. Journal of the American Society for Information Science and Technology, 59(5), 792-804

Coney, S. (1998, December 13). Trading firms out of reach. Sunday Star Times, p.6.

Conrad, F.G., Couper, M.P., Tourangeau, R. \& Petychev, A. (2006). Use and non-use of clarification features in web surveys. Journal of Official Statistics, 22(2), 245-269.

Controller and Auditor-General. (2007). Statements of corporate intent: Legislative compliance and performance reporting. Retrieved from http://www.oag.govt.nz/2007/corporate-intent/docs/oag-corporate-intent.pdf

Controller and Auditor-General. (2012). Auckland Council: Transition and emerging challenges. Retrieved from http://www.oag.govt.nz/2012/aucklandcouncil/docs/auckland-council.pdf

Department of Internal Affairs. (2011). Councils A-Z. Retrieved May 28, 2013, from http://www.localcouncils.govt.nz/lgip.nsf/wpg_url/Profiles-Index 
DeRouvray, C. \& Couper, M.P. (2002). Designing a strategy for reducing "no opinion" responses in web-based surveys. Social Science Computer Review, 20(1), 3-9.

Dillman, D.A., Smyth, J.D. \& Christian, L.M. (2009). Internet, mail and mixed-mode surveys: The tailored design method ( $3^{\text {rd }}$ ed.). Hoboken, NJ: John Wiley \& Sons Inc.

Ending of tourism trust cost $\$ 100,000$. (2012, December 22). The Timaru Herald. Retrieved from http://www.stuff.co.nz/timaru-herald/news/8111241/Ending-of-tourismtrust-cost-100-000

Government Administration Committee. (2005). Public Records Bill (189-2) as reported by the Government Administration Committee. Retrieved from New Zealand Parliament: http://www.parliament.nz/NR/rdonlyres/04C810BB-8A5B-4E1B-B44A47DD1F7D64F5/48090/DBSCH_SCR_3021_31291.pdf

Hood, C. (1995). The "new public management" in the 1980s: Variations on a theme. Accounting, Organization and Society, 20(2/3), 93-109.

Hood, C. (2007). What happens when transparency meets blame-avoidance? Public Management Review, 9(2), 191-210.

Howie, C. (2012, December 23). Agencies failing supercity. The New Zealand Herald. Retrieved from http://www.nzherald.co.nz/nz/news/article.cfm?c_id=1\&objectid=10855746

Jimerson, R.C. (2009). Archives power: Memory, accountability, and social justice. Chicago, IL: Society of American Archivists. 
Kaplowitz, M.D., Lupi, F., Couper, M.P. \& Thorp, L. (2012). The effect of invitation design on web survey response rates. Social Science Computer Review, 30(3), 339-349.

Larsen Consulting. (2012). Governance review of all companies in which Dunedin City Council and/or Dunedin City Holdings Ltd has an equity interest of 50\% or more. Retrieved from Dunedin City Council: http://www.dunedin.govt.nz/yourcouncil/latest-news/august-2011/larsen-report-now-available

Leedy, P.D. \& Ormrod, J.E. (2012). Practical research: Planning and design (International edition; $10^{\text {th }}$ ed.). United States of America: Pearson Education.

Levin, J. \& Fox, J.A. (2011). Elementary statistics in social research: The essentials (3 ${ }^{\text {rd }}$ ed.). Boston, MA: Allyn \& Bacon.

Lineham, R. (2010). The role of the holding company and its governance arrangements. In Local Government Intensive, 20 August 2010 (pp. 23-29). Wellington, New Zealand: New Zealand Law Society.

Local Government Act 1974. Retrieved January 14, 2013, from: http://legislation.knowledge-basket.co.nz/gpacts/reprint/text/1974/an/066.html

Local Government Act 2002. Retrieved August 19, 2012, from: http://www.legislation.govt.nz/act/public/2002/0084/latest/DLM170873.html

Local Government (Auckland Council) Act 2009. Retrieved May 22, 2013, from: http://www.legislation.govt.nz/act/public/2009/0032/latest/DLM2044909.html

Local Government (Council-Controlled Organisations) Amendment Bill. (2012). First reading. Retrieved January 14, 2013, from: http://www.parliament.nz/en- 
NZ/PB/Debates/Debates/f/a/1/50HansD_20120919_00000032-Local-

Government-Council-Controlled-Organisations.htm

Local Government Amendment Act (No.2) 1989. Retrieved January 14, 2013, from:

http://legislation.knowledge-basket.co.nz/gpacts/public/text/1989/an/029.html

Lozano, L.M., García-Cueto E. \& Muñiz, J. (2008). Effect of the number of response categories on the reliability and validity of rating scales. Methodology, 4(2), 73-79.

Luke, B. (2010). Examining accountability dimensions in state-owned enterprises. Financial Accountability \& Management, 26(2), 134-162.

Matzat, U., Snijders, C. \& van der Horst, W. (2009). Effects of different types of progress indicators on drop-out rates in web surveys. Social Psychology, 40(1), 43-52.

McKemmish, S. (2001). Placing records continuum theory and practice. Archival Science, 1(4), 333-359.

Montgomery Watson Harza Consultants. (2009). Analysis of council organisations. Retrieved from Local Government New Zealand: http://www.localcouncils.govt.nz/lgip.nsf/Files/PDF/\$file/councilorgs.pdf

New Zealand Law Commission. (2010). The public's right to know: A review of the Official Information Act 1982 and parts 1-6 of the Local Government Official Information and Meetings Act 1987. Retrieved from http://www.lawcom.govt.nz/sites/default/files/publications/2010/09/publics_rig ht_to_know_280910_0.pdf

Nielsen. (2010). Government recordkeeping survey report 2010 - Local authorities. Retrieved from Archives New Zealand: http://www.archives.govt.nz/full-report2010-government-recordkeeping-survey-local-authorities 
Oliver, G. (2011). Organisational culture for information managers. Oxford, United Kingdom: Chandos Publishing.

Oliver, G.C. \& Konsa, K. (2012). Dismantling bureaucracies: Consequences for recordkeeping in New Zealand and Estonia. Journal of the Society of Archivists, 33(1), 89107.

Palmer, K. (2012). Local authorities law in New Zealand. Wellington, New Zealand: Brookers Ltd.

Porter, D.R. (2011). Local government accountability: An investigation into local government processes of assurance in the context of the Dunedin stadium. (Unpublished master's thesis, University of Otago, 2011). Retrieved from http://hdl.handle.net/10523/2031

Public Records Act 2005. Retrieved August 19, 2012, from: http://www.legislation.govt.nz/act/public/2005/0040/latest/DLM345529.html

Qualtrics. (n.d.). Survey research suite. Retrieved January 21, 2013, from: http://www.qualtrics.com/university/researchsuite/

Rawlins, B. (2009). Give the emperor a mirror: Toward developing a stakeholder measurement of organizational transparency. Journal of Public Relations Research, 21(1), 71-99.

Rea, L.M. \& Parker, R.A. (2005). Designing and conducting survey research: A comprehensive guide. San Francisco, CA: Jossey-Bass.

Reid, M. (2010). Strengthening local government and community governance in New Zealand. (Unpublished doctoral thesis, Victoria University of Wellington, 2010). Retrieved from http://hdl.handle.net/10063/1537 
Roper, J. \& Schoenberger-Orgad, M. (2011). State-owned enterprises: Issues of accountability and legitimacy. Management Communication Quarterly, 25(4), 693709.

Shepherd, E., Stevenson, A. \& Flinn, A. (2010). Information governance, records management, and the freedom of information: A study of local government authorities in England. Government Information Quarterly, 27(2010), 337-345.

Sorry tale that should not be hidden from public view. (2009, April 18). The Press, p.17.

State-Owned Enterprises Act 1986. Retrieved January 14, 2013, from: http://legislation.knowledge-basket.co.nz/gpacts/public/text/1986/an/124.html

State-Owned Enterprises (Ombudsmen and Official Information Acts) Committee. (1990). Report of the State-Owned Enterprises (Ombudsmen and Official Information Acts) Committee on the review of the effect of the Ombudsmen Act 1975 and the Official Information Act 1982 on the operation of State enterprises. Wellington, New Zealand: Government Printer.

Stern, M.J., Dillman, D.A. \& Smyth, J.D. (2007). Visual design, order effects, and respondent characteristics in a self-administered survey. Survey Research Methods, 1(3), 121138.

Stieger, S., Reips, U.D. \& Voracek, M. (2007). Forced-response in online surveys: Bias from reactance and an increase in sex-specific dropout. Journal of the American Society for Information Science and Technology, 58(11), 1653-1660.

Taylor, S. (2010). CCOs: Governance at a distance - how close is close enough? The Taranaki Investment Management Limited Story. In Local Government Intensive, 20 August 2010 (pp. 37-44). Wellington, New Zealand: New Zealand Law Society. 
Vincente, P. \& Reis, E. (2010). Using questionnaire design to fight nonresponse bias in web surveys. Social Science Computer Review, 28(2), 251-267.

White, N. (2007). Free and frank: Making the Official Information Act 1982 work better. Wellington, New Zealand: Institute of Policy Studies, School of Government, Victoria University of Wellington.

Worthy, B., Amos, J., Hazell, R. \& Bourke, G. (2011). Town hall transparency? The impact of freedom of information on local government in England. Retrieved from University College London, Constitution Unit: http://www.ucl.ac.uk/constitutionunit/publications/tabs/unit-publications/155.pdf 
Name: Vanessa King

Student ID: 300069813

Word count: 11,550 


\section{Appendix I: Information request sent to local bodies, 29 November 2012}

Greetings/Tena koutou

I request the following information about your Council and its council-controlled organisations (CCOs) to assist with planning my research for a Master of Information Studies at Victoria University of Wellington.

About the Council:

1. The approximate number of staff employed by the Council.

2. The approximate population served by the Council.

3. The name of the position within the Council that oversees records management.

4. The most appropriate email address for contacting the person in that position (I am planning to distribute an online survey at a later date).

About the Council's council-controlled organisations (CCOs) and council-controlled trading organisations (CCTOs):

1. The names of all CCOs or CCTOs, as they are defined under section 6 of the Local Government Act 2002, in which the Council has a controlling interest, whether through shareholding or other rights.

2. The percentage of shareholding or control the Council has in each of those CCOs and CCTOs.

3. The approximate number of staff employed by each of those CCOs and CCTOs.

4. The name of the position within each of those CCOs and CCTOs that oversees records management.

5. The most appropriate email addresses for contacting the people in those positions (I am planning to distribute an online survey at a later date).

6. If there is no position overseeing records management, the name of the CEO or Chair of the CCO or CCTO.

Kind regards/Nga mihi

Vanessa King 


\section{Appendix II: Survey information sheet and questions}

An investigation into the adoption of responsibility for records management programmes in council-controlled organisations.

Since 1989 New Zealand's local authorities have been permitted to establish what are presently called council-controlled organisations. According to local authority annual reports in 2012 there were approximately 180 CCOs, engaged in a variety of activities. CCOs play an important role in the conduct of local government's affairs, and in recognition of this they are subject to the Public Records Act 2005. Yet, there has been very little research into their records management. I have developed a short survey to explore the level of involvement local authorities have in their CCOs' records management, as well as the nature of CCOs' records management programmes. Findings from this survey will provide New Zealand's records management community with a better understanding of the records management issues CCOs face.

I am a student at Victoria University of Wellington and this research is being conducted in partial fulfilment of a Master of Information Studies.

The survey should only take 5-10 minutes to complete, and will remain open until 19 April 2013.

Responses are strictly anonymous and no identifying information is collected. All opinions and data will be reported in an aggregated form in such a way that individual persons or organisations are not identifiable.

Participation is voluntary and you are implying consent to participate by completing and submitting this online survey. The survey has received ethical approval from the School of Information Management Human Ethics Committee at Victoria University of Wellington. The data collected from this survey will be stored in a password-protected file for up to two years, after which it will be deleted. Access to the data will be restricted to the researcher and their supervisor.

Participants who would like to be informed of the results of the research can contact the researcher at the email address provided.

If you have any questions please contact:

Researcher: Vanessa King Supervisor: Dr Gillian Oliver 


\section{Definitions}

When completing the survey keep the following definitions in mind:

\section{Council-controlled organisation (CCO)}

A company or entity in which one or more local authorities has a controlling interest, whether directly or indirectly, through shareholding, voting rights or the right to appoint directors, managers (however described) or trustees (Local Government Act, 2002, Section 6).

\section{Council-controlled trading organisation (CCTO)}

"A council-controlled organisation that operates a trading undertaking for the purpose of making a profit," (Local Government Act, 2002, Section 6).

\section{Local authority}

A regional, territorial (city and district) or unitary council.

The first set of questions is about the nature of your organisation.

\section{Q1 What type of organisation are you responding on behalf of?}

Note: A CCO can be a company or a "partnership, trust, arrangement for the sharing of profits, union of interest, co-operation, joint venture, or other similar arrangement," (Local Government Act, 2002, Section 6).

○ Regional council

- Territorial council i.e. a city or district council

- Unitary council i.e. a territorial council with regional council responsibilities

- Council-controlled organisation (CCO)

- Council-controlled trading organisation (CCTO)

- Subsidiary of a CCO or CCTO

\section{Skip Logic:}

If Regional council is selected, then skip to Q17

If Territorial council is selected, then skip to Q17

If Unitary council is selected, then skip to Q17 
From this point onward the phrase "your organisation" refers to the organisation you are responding on behalf of.

Q2 Is your organisation currently exempt from the status of CCO under section 7 of the Local Government Act 2002?
○ Yes
○ No
- Don't know

\section{Skip Logic:}

If Yes is selected, the skip to end of survey

Q3 How many staff are employed by your organisation?
○ Less than 10 staff
- 10-50 staff
○ 50-100 staff
- 100-500 staff
- More than 500 staff
- Don't know

Q4 How many local authorities hold shares, voting rights or the right to appoint directors, managers (however described) or trustees in your organisation?
○ 1
$\circ 2$
- 3 or more
- Don't know 
Q5 Which one of these activities best describes your organisation's interests?

- Culture and recreation

- Economic development

- Governance and investment e.g. a holding company

- Infrastructure e.g. transportation, water management, communications or solid waste

- Primary industry e.g. forestry

- Service industry e.g. health care or tourism

- Shared services

- Other (please specify)

The next set of questions is about local authority involvement in your organisation's records management programme.

Note: A record is information created, received and managed as evidence of your organisation's affairs (e.g. minutes from a meeting of the board of directors/trustees, or e-mail correspondence negotiating a contract).

\section{Display Logic:}

If the answer to Q1 equals CCO or CCTO, display Q6

Q6 Are any of the local authorities that control your organisation involved with your records management programme?
○ Yes
- No
- Don't know

Display Logic:

If the answer to Q1 equals Subsidiary of a CCO or CCTO, display Q7

Q7 Is the local authority that controls your parent company (i.e. the CCO or CCTO above your organisation) involved with your organisation's records management programme?
○ Yes
- No
○ Don't know 


\section{Display Logic:}

If the answer to Q6 or Q7 equals Yes, display Q8

Q8 In what ways is the local authority involved with your organisation's records management programme?

\begin{tabular}{|l|c|c|c|c|c|c|}
\hline & $\begin{array}{c}\text { All of } \\
\text { the time }\end{array}$ & Often & Sometimes & Rarely & Never & $\begin{array}{c}\text { Don't } \\
\text { know }\end{array}$ \\
\hline $\begin{array}{l}\text { Local authority } \\
\text { records } \\
\text { management staff } \\
\text { provide my } \\
\text { organisation with } \\
\text { advice }\end{array}$ & 0 & 0 & 0 & 0 & 0 & 0 \\
\hline $\begin{array}{l}\text { My organisation } \\
\text { manages its paper } \\
\text { records in systems } \\
\text { administered by } \\
\text { the local authority }\end{array}$ & 0 & 0 & 0 & 0 & 0 & 0 \\
\hline $\begin{array}{l}\text { My organisation } \\
\text { manages its } \\
\text { electronic records } \\
\text { in systems } \\
\text { administered by } \\
\text { the local authority } \\
\text { e.g. in an } \\
\text { organisational } \\
\text { EDRMS }\end{array}$ & 0 & 0 & 0 & 0 & 0 & 0 \\
\hline $\begin{array}{l}\text { My organisation } \\
\text { has adopted the } \\
\text { local authority's } \\
\text { records } \\
\text { management } \\
\text { policies }\end{array}$ & 0 & 0 & 0 & 0 & 0 & 0 \\
\hline
\end{tabular}




\begin{tabular}{|l|c|c|c|c|c|c|}
\hline & $\begin{array}{c}\text { All of } \\
\text { the time }\end{array}$ & Often & Sometimes & Rarely & Never & $\begin{array}{c}\text { Don't } \\
\text { know }\end{array}$ \\
\hline $\begin{array}{l}\text { My organisation } \\
\text { has adopted the } \\
\text { local authority's } \\
\text { records } \\
\text { management } \\
\text { procedures }\end{array}$ & 0 & 0 & 0 & 0 & 0 & 0 \\
\hline $\begin{array}{l}\text { Staff from my } \\
\text { organisation } \\
\text { participate in the } \\
\text { local authority's } \\
\text { records } \\
\text { management } \\
\text { training } \\
\text { programme }\end{array}$ & 0 & 0 & 0 & 0 & 0 & 0 \\
\hline $\begin{array}{l}\text { My organisation } \\
\text { transfers records } \\
\text { which have } \\
\text { continuing value } \\
\text { (i.e. archives) to } \\
\text { the local authority }\end{array}$ & 0 & 0 & 0 & 0 & 0 & 0 \\
\hline
\end{tabular}

\section{Display Logic:}

\section{If answer to Q6 or Q7 equals Yes, display Q9}

Q9 Are there any other ways in which the local authority is involved with your organisation's records management programme? (Please specify)

\section{Display Logic:}

If answer to Q6 or Q7 equals Yes, display Q10 
Q10 What kind of agreement do you have in place regarding the local authority's involvement with your organisation's records management programme?
- A formal agreement
○ We are currently developing a formal agreement
- An informal agreement
○ No agreement
$\circ$ Other (please specify)
- Don't know

Q11 Do you have any further comments about the level of local authority involvement in your organisation's records management programme? (Please specify)

The final set of questions is about the nature of your organisation's records management programme.

Note: A records is information created, received and managed as evidence of your organisation's affairs (e.g. minutes from a meeting of the board of directors/trustees, or e-mail correspondence negotiating a contract).

Q12 What records management planning activities does your organisation have in place?

\begin{tabular}{|l|c|c|c|c|c|c|}
\hline & $\begin{array}{c}\text { Definitely } \\
\text { yes }\end{array}$ & $\begin{array}{c}\text { Probably } \\
\text { yes }\end{array}$ & Partially & $\begin{array}{c}\text { Probably } \\
\text { not }\end{array}$ & $\begin{array}{c}\text { Definitely } \\
\text { not }\end{array}$ & $\begin{array}{c}\text { Don't } \\
\text { know }\end{array}$ \\
\hline $\begin{array}{l}\text { There is a } \\
\text { senior } \\
\text { manager who } \\
\text { sponsors } \\
\text { records } \\
\text { management }\end{array}$ & 0 & 0 & 0 & 0 & 0 & 0 \\
\hline
\end{tabular}




\begin{tabular}{|l|c|c|c|c|c|c|}
\hline & $\begin{array}{c}\text { Definitely } \\
\text { yes }\end{array}$ & $\begin{array}{c}\text { Probably } \\
\text { yes }\end{array}$ & Partially & $\begin{array}{c}\text { Probably } \\
\text { not }\end{array}$ & $\begin{array}{c}\text { Definitely } \\
\text { not }\end{array}$ & $\begin{array}{c}\text { Don't } \\
\text { know }\end{array}$ \\
\hline $\begin{array}{l}\text { Systems } \\
\text { (both paper } \\
\text { and } \\
\text { electronic) } \\
\text { which create } \\
\text { records have } \\
\text { been } \\
\text { identified }\end{array}$ & 0 & 0 & 0 & 0 & 0 & 0 \\
\hline $\begin{array}{l}\text { Systems } \\
\text { (both paper } \\
\text { and } \\
\text { electronic) } \\
\text { which } \\
\text { manage } \\
\text { records have } \\
\text { been } \\
\text { identified }\end{array}$ & 0 & 0 & 0 & 0 & 0 & 0 \\
\hline $\begin{array}{l}\text { There are } \\
\text { formal } \\
\text { records } \\
\text { management } \\
\text { policies }\end{array}$ & 0 & 0 & 0 & 0 & 0 & 0 \\
\hline $\begin{array}{l}\text { There are } \\
\text { formal } \\
\text { procedures } \\
\text { for creating } \\
\text { and filing } \\
\text { paper } \\
\text { records }\end{array}$ & 0 & 0 & 0 & 0 & 0 & 0 \\
\hline $\begin{array}{l}\text { There are } \\
\text { formal } \\
\text { procedures } \\
\text { for creating } \\
\text { and filing } \\
\text { electronic } \\
\text { records }\end{array}$ & 0 & 0 & 0 & 0 & & 0 \\
\hline
\end{tabular}




\begin{tabular}{|l|c|c|c|c|c|c|}
\hline & $\begin{array}{c}\text { Definitely } \\
\text { yes }\end{array}$ & $\begin{array}{c}\text { Probably } \\
\text { yes }\end{array}$ & Partially & $\begin{array}{c}\text { Probably } \\
\text { not }\end{array}$ & $\begin{array}{c}\text { Definitely } \\
\text { not }\end{array}$ & $\begin{array}{c}\text { Don't } \\
\text { know }\end{array}$ \\
\hline $\begin{array}{l}\text { Records that } \\
\text { are critical } \\
\text { for the } \\
\text { functioning of } \\
\text { the } \\
\text { organisation } \\
\text { are identified }\end{array}$ & 0 & 0 & 0 & 0 & 0 & 0 \\
\hline $\begin{array}{l}\text { There is a } \\
\text { disaster } \\
\text { recovery plan } \\
\text { for records }\end{array}$ & 0 & 0 & 0 & 0 & 0 & 0 \\
\hline $\begin{array}{l}\text { New business } \\
\text { systems are } \\
\text { designed to } \\
\text { incorporate } \\
\text { records } \\
\text { management } \\
\text { requirements }\end{array}$ & 0 & 0 & 0 & 0 & 0 & 0 \\
\hline $\begin{array}{l}\text { There is a } \\
\text { current } \\
\text { records } \\
\text { management } \\
\text { plan or } \\
\text { strategy }\end{array}$ & 0 & 0 & 0 & 0 & 0 & 0 \\
\hline
\end{tabular}

Q13 What records management resourcing activities does your organisation have in place?

\begin{tabular}{|l|c|c|c|c|c|c|}
\hline & $\begin{array}{c}\text { Definitely } \\
\text { yes }\end{array}$ & $\begin{array}{c}\text { Probably } \\
\text { yes }\end{array}$ & Partially & $\begin{array}{c}\text { Probably } \\
\text { not }\end{array}$ & $\begin{array}{c}\text { Definitely } \\
\text { not }\end{array}$ & $\begin{array}{c}\text { Don't } \\
\text { know }\end{array}$ \\
\hline $\begin{array}{l}\text { Records } \\
\text { management } \\
\text { roles are } \\
\text { documented }\end{array}$ & 0 & $\circ$ & 0 & 0 & 0 & 0 \\
\hline
\end{tabular}




\begin{tabular}{|l|c|c|c|c|c|c|}
\hline & $\begin{array}{c}\text { Definitely } \\
\text { yes }\end{array}$ & $\begin{array}{c}\text { Probably } \\
\text { yes }\end{array}$ & Partially & $\begin{array}{c}\text { Probably } \\
\text { not }\end{array}$ & $\begin{array}{c}\text { Definitely } \\
\text { not }\end{array}$ & $\begin{array}{c}\text { Don't } \\
\text { know }\end{array}$ \\
\hline $\begin{array}{l}\text { Records } \\
\text { management } \\
\text { responsibilities } \\
\text { are } \\
\text { documented }\end{array}$ & 0 & 0 & 0 & 0 & 0 & 0 \\
\hline $\begin{array}{l}\text { Records } \\
\text { management } \\
\text { responsibilities } \\
\text { are } \\
\text { communicated } \\
\text { to staff }\end{array}$ & 0 & 0 & 0 & 0 & 0 & 0 \\
\hline $\begin{array}{l}\text { Specialised } \\
\text { records } \\
\text { management } \\
\text { staff are } \\
\text { appointed }\end{array}$ & 0 & 0 & 0 & 0 & 0 & 0 \\
\hline
\end{tabular}

Q14 What records management training activities does your organisation have in place?

\begin{tabular}{|l|c|c|c|c|c|c|}
\hline & $\begin{array}{c}\text { Definitely } \\
\text { yes }\end{array}$ & $\begin{array}{c}\text { Probably } \\
\text { yes }\end{array}$ & Partially & $\begin{array}{c}\text { Probably } \\
\text { not }\end{array}$ & $\begin{array}{c}\text { Definitely } \\
\text { not }\end{array}$ & $\begin{array}{c}\text { Don't } \\
\text { know }\end{array}$ \\
\hline $\begin{array}{l}\text { The records } \\
\text { management } \\
\text { training } \\
\text { needs of } \\
\text { records } \\
\text { management } \\
\text { staff have } \\
\text { been } \\
\text { identified }\end{array}$ & 0 & 0 & 0 & 0 & 0 & 0 \\
\hline
\end{tabular}




\begin{tabular}{|l|c|c|c|c|c|c|}
\hline & $\begin{array}{c}\text { Definitely } \\
\text { yes }\end{array}$ & $\begin{array}{c}\text { Probably } \\
\text { yes }\end{array}$ & Partially & $\begin{array}{c}\text { Probably } \\
\text { not }\end{array}$ & $\begin{array}{c}\text { Definitely } \\
\text { not }\end{array}$ & $\begin{array}{c}\text { Don't } \\
\text { know }\end{array}$ \\
\hline $\begin{array}{l}\text { The records } \\
\text { management } \\
\text { training } \\
\text { needs of all } \\
\text { other staff } \\
\text { have been } \\
\text { identified }\end{array}$ & 0 & 0 & 0 & 0 & 0 & 0 \\
\hline $\begin{array}{l}\text { Records } \\
\text { management } \\
\text { staff are } \\
\text { responsible } \\
\text { for defining } \\
\text { records } \\
\text { management } \\
\text { training } \\
\text { requirements }\end{array}$ & 0 & 0 & 0 & 0 & 0 & 0 \\
\hline $\begin{array}{l}\text { There is a } \\
\text { records } \\
\text { management } \\
\text { training plan }\end{array}$ & 0 & 0 & 0 & 0 & 0 & 0 \\
\hline $\begin{array}{l}\text { Staff receive } \\
\text { records } \\
\text { management } \\
\text { training }\end{array}$ & 0 & 0 & 0 & 0 & 0 & 0 \\
\hline
\end{tabular}

Q15 What records management monitoring and reporting activities does your organisation have in place?

\begin{tabular}{|l|c|c|c|c|c|c|}
\hline & $\begin{array}{c}\text { Definitely } \\
\text { yes }\end{array}$ & $\begin{array}{c}\text { Probably } \\
\text { yes }\end{array}$ & Partially & $\begin{array}{c}\text { Probably } \\
\text { not }\end{array}$ & $\begin{array}{c}\text { Definitely } \\
\text { not }\end{array}$ & $\begin{array}{c}\text { Don't } \\
\text { know }\end{array}$ \\
\hline $\begin{array}{l}\text { Records } \\
\text { management } \\
\text { reporting } \\
\text { requirements } \\
\text { are } \\
\text { documented }\end{array}$ & 0 & 0 & 0 & 0 & 0 & 0 \\
\hline
\end{tabular}




\begin{tabular}{|l|c|c|c|c|c|c|}
\hline & $\begin{array}{c}\text { Definitely } \\
\text { yes }\end{array}$ & $\begin{array}{c}\text { Probably } \\
\text { yes }\end{array}$ & Partially & $\begin{array}{c}\text { Probably } \\
\text { not }\end{array}$ & $\begin{array}{c}\text { Definitely } \\
\text { not }\end{array}$ & $\begin{array}{c}\text { Don't } \\
\text { know }\end{array}$ \\
\hline $\begin{array}{l}\text { Records } \\
\text { management } \\
\text { staff monitor } \\
\text { records } \\
\text { management } \\
\text { practices }\end{array}$ & 0 & 0 & 0 & 0 & 0 & 0 \\
\hline $\begin{array}{l}\text { Records } \\
\text { management } \\
\text { staff report } \\
\text { on records } \\
\text { management } \\
\text { practices }\end{array}$ & 0 & 0 & 0 & 0 & 0 & 0 \\
\hline $\begin{array}{l}\text { The results of } \\
\text { monitoring } \\
\text { are reported } \\
\text { to the } \\
\text { appropriate } \\
\text { level of } \\
\text { management }\end{array}$ & 0 & 0 & 0 & 0 & 0 & 0 \\
\hline $\begin{array}{l}\text { The creation } \\
\text { of records is } \\
\text { routinely } \\
\text { monitored }\end{array}$ & 0 & 0 & 0 & 0 & 0 & 0 \\
\hline $\begin{array}{l}\text { The capture } \\
\text { of records in } \\
\text { systems is } \\
\text { routinely } \\
\text { monitored }\end{array}$ & 0 & 0 & 0 & 0 & 0 & 0 \\
\hline
\end{tabular}


Q16 Do you have any further comments about records management in your organisation? (Please specify)

If you wish to review any of your answers prior to submission select the PREVIOUS button at the bottom of the page.

If you are satisfied with your answers please select COMPLETED then the NEXT button.

○ Completed

\section{Skip Logic:}

If Completed is selected, then skip to the end of the survey

Q17 How many staff are employed by your organisation?
○ Less than 50 staff
○ 50-100 staff
- 100-500 staff
○ 500-1000 staff
- More than 1000 staff
- Don't know

Q18 How many CCOs and/or CCTOs does your organisation have a controlling interest in?
$\circ 1$
$\circ 2$
- 3 or more
- Some - I don't know the exact number
○ None
- Don't know

\section{Skip Logic:}

If None is selected, then skip to the end of the survey 
The main set of questions is about your organisation's level of involvement with records management programmes in its CCOs and/or CCTOs.

Note: A records is information created, received and managed as evidence of your organisation's affairs (e.g. minutes from a meeting of the Council, or e-mail correspondence negotiating a contract).

Q19 Is your organisation involved with the records management programme(s) in its CCOs and/or CCTOs?
- Yes - all of them
○ Yes - some of them
○ No
- Don't know

Display Logic:

If the answer to Q19 is Yes - all of them or Yes - some of them, display Q20

Q20 In what ways is your organisation involved with the records management programme(s) in its CCOs and/or CCTOs?

\begin{tabular}{|l|c|c|c|c|c|c|}
\hline & $\begin{array}{c}\text { All of } \\
\text { the time }\end{array}$ & Often & Sometimes & Rarely & Never & $\begin{array}{c}\text { Don't } \\
\text { know }\end{array}$ \\
\hline $\begin{array}{l}\text { Records } \\
\text { management staff } \\
\text { from my } \\
\text { organisation } \\
\text { provide the } \\
\text { CCOs/CCTOs with } \\
\text { advice }\end{array}$ & 0 & 0 & 0 & 0 & 0 & 0 \\
\hline $\begin{array}{l}\text { The CCOs/CCTOs } \\
\text { manage their paper } \\
\text { records in systems } \\
\text { administered by } \\
\text { my organisation }\end{array}$ & 0 & 0 & 0 & 0 & 0 & 0 \\
\hline
\end{tabular}




\begin{tabular}{|l|c|c|c|c|c|c|}
\hline & $\begin{array}{c}\text { All of } \\
\text { the time }\end{array}$ & Often & Sometimes & Rarely & Never & $\begin{array}{c}\text { Don't } \\
\text { know }\end{array}$ \\
\hline $\begin{array}{l}\text { The CCOs/CCTOs } \\
\text { manage their } \\
\text { electronic records } \\
\text { in systems } \\
\text { administered by } \\
\text { my organisation } \\
\text { e.g. in an } \\
\text { organisational } \\
\text { EDRMS }\end{array}$ & 0 & 0 & 0 & 0 & 0 & 0 \\
\hline $\begin{array}{l}\text { The CCOs/CCTOs } \\
\text { have adopted my } \\
\text { organisation's } \\
\text { records } \\
\text { management } \\
\text { policies }\end{array}$ & 0 & 0 & 0 & 0 & 0 & 0 \\
\hline $\begin{array}{l}\text { The CCOs/CCTOs } \\
\text { have adopted my } \\
\text { organisation's } \\
\text { records } \\
\text { management } \\
\text { procedures }\end{array}$ & 0 & 0 & 0 & 0 & 0 & 0 \\
\hline $\begin{array}{l}\text { The CCO/CCTO } \\
\text { staff participate in } \\
\text { my organisation's } \\
\text { records } \\
\text { management } \\
\text { training } \\
\text { programme }\end{array}$ & 0 & 0 & 0 & 0 & 0 & 0 \\
\hline $\begin{array}{l}\text { The CCOs/CCTOs } \\
\text { transfer records } \\
\text { which have } \\
\text { continuing value } \\
\text { (i.e. archives) to my } \\
\text { organisation }\end{array}$ & 0 & 0 & 0 & 0 & 0 & 0 \\
\hline
\end{tabular}




\section{Display Logic:}

If the answer to Q19 is Yes - all of them or Yes - some of them, display Q21

Q21 Are there any other ways in which your organisation is involved with the records management programme(s) in its CCOs and/or CCTOs? (Please specify)

\section{Display Logic:}

If the answer to Q19 is Yes - all of them or Yes - some of them, display Q22

Q22 What kind of agreement do you have in place regarding your organisation's involvement with the records management programme(s) in its CCOs and/or CCTOs?
- A formal agreement
- We are currently developing a formal agreement
○ An informal agreement
- No agreement
- Other (please specify)
- Don't know

Q23 Do you have any comments about why your organisation is OR is not involved with the records management programme(s) in its CCOs and/or CCTOs? (Please specify)

If you wish to review any of your answers prior to submission select the PREVIOUS button at the bottom of the page.

If you are satisfied with your answers please select COMPLETED then the NEXT button.

○ Completed 


\section{Appendix III: Email invitation sent to local body records managers}

Email subject: Survey of records management in council-controlled organisations

An investigation into the adoption of responsibility for records management programmes in council-controlled organisations

This email is an invitation to participate in a short, anonymous survey exploring the level of involvement local authorities have in their CCOs' records management, as well as the nature of CCOs' records management programmes.

Your organisation has identified you as responsible for its records management and has provided me with your email address. If you are not the appropriate contact I would be grateful if you would forward this email to the person responsible for records management in your organisation. Even if your organisation is not involved with records management in its CCOs your response will be valuable.

Since 1989 New Zealand's local authorities have been permitted to establish what are presently called council-controlled organisations. According to local authority annual reports in 2012 there were approximately 180 CCOs, engaged in a variety of activities. CCOs play an important role in the conduct of local government's affairs, and in recognition of this they are subject to the Public Records Act 2005. Yet, there has been very little research into their records management. Findings from this survey will provide New Zealand's records management community with a better understanding of the records management issues CCOs face.

I am a student at Victoria University of Wellington and this research is being conducted in partial fulfilment of a Master of Information Studies. Your participation is very much appreciated.

The survey should only take 5-10 minutes to complete, and will remain open until 19 April 2013. Please click this link for further information and to begin the survey: [Insert survey link]

Kind regards

Vanessa King Master of Information Studies candidate Victoria University of Wellington 


\section{Appendix IV: Email invitation sent to CCOs}

Email subject: Survey of records management in council-controlled organisations

An investigation into the adoption of responsibility for records management programmes in council-controlled organisations

This email is an invitation to participate in a short, anonymous survey exploring the level of involvement local authorities have in their CCOs' records management, as well as the nature of CCOs' records management programmes.

The local authority that has a controlling interest in your organisation has provided me with your email address. If you are not the appropriate contact I would be grateful if you would forward this email to the person responsible for managing records in your organisation.

Since 1989 New Zealand's local authorities have been permitted to establish what are presently called council-controlled organisations. According to local authority annual reports in 2012 there were approximately 180 CCOs, engaged in a variety of activities. CCOs play an important role in the conduct of local government's affairs, and in recognition of this they are subject to the Public Records Act 2005. Yet, there has been very little research into their records management. Findings from this survey will provide New Zealand's records management community with a better understanding of the records management issues CCOs face.

I am a student at Victoria University of Wellington and this research is being conducted in partial fulfilment of a Master of Information Studies. Your participation is very much appreciated.

The survey should only take 5-10 minutes to complete, and will remain open until 19 April 2013. Please click this link for further information and to begin the survey: [Insert survey link]

Kind regards

Vanessa King

Master of Information Studies candidate

Victoria University of Wellington 


\section{Appendix V: Follow-up email}

Email subject: Reminder: Survey of records management in council-controlled organisations

An investigation into the adoption of responsibility for records management programmes in council-controlled organisations

On 5 April I emailed you an invitation to participate in a short, anonymous survey exploring the level of involvement local authorities have in their CCOs' records management, as well as the nature of CCOs' records management programmes.

If you have already completed this survey, or forwarded it to the appropriate person in your organisation, I would like to thank you very much for your time. If not, please consider doing so. The survey should only take 5-10 minutes to complete, and will remain open until 19 April 2013.

Since 1989 New Zealand's local authorities have been permitted to establish what are presently called council-controlled organisations. According to local authority annual reports in 2012 there were approximately 180 CCOs, engaged in a variety of activities. CCOs play an important role in the conduct of local government's affairs, and in recognition of this they are subject to the Public Records Act 2005. Yet, there has been very little research into their records management. Findings from this survey will provide New Zealand's records management community with a better understanding of the records management issues CCOs face.

I am a student at Victoria University of Wellington and this research is being conducted in partial fulfilment of a Master of Information Studies. Your participation is very much appreciated.

Please click this link for further information and to begin the survey:

\section{[Insert survey link]}

Kind regards

Vanessa King

Master of Information Studies candidate

Victoria University of Wellington 